\title{
Impacts of Tides and Typhoon Fanapi (2010) on Seas Around Taiwan
}

\author{
Dong S. Ko ${ }^{1, *}$, Shenn-Yu Chao ${ }^{2}$, Chun-Chieh Wu ${ }^{3}$, I-I Lin ${ }^{3}$, and Sen Jan ${ }^{4}$ \\ ${ }^{1}$ Oceanography Division, Naval Research Laboratory, Stennis Space Center, Mississippi, U.S.A. \\ ${ }^{2}$ Horn Point Laboratory, University of Maryland Center for Environmental Science, Cambridge, Maryland, U.S.A. \\ ${ }^{3}$ Department of Atmospheric Sciences, National Taiwan University, Taipei, Taiwan, R.O.C. \\ ${ }^{4}$ Institute of Oceanography, National Taiwan University, Taipei, Taiwan, R.O.C.
}

Received 8 October 2014, revised 27 October 2015, accepted 28 October 2015

\begin{abstract}
We used satellite data, typhoon-resolving atmospheric forcing and a data assimilating ocean model, the East Asian Seas Nowcast/Forecast System (EASNFS), to investigate circulation and three upwelling regions perturbed by tides and Typhoon Fanapi (2010) in the seas around Taiwan. The three upwelling areas located off northeast Taiwan, off southeast China and over the Penghu Channel off southwest Taiwan are normally limited in expanse before Fanapi. The tidal currents enhance all three. To cope with typhoon strength atmospheric forcing, we applied typhoon-resolving Weather Research and Forecasting (WRF) model wind fields that significantly enhanced Fanapi-induced upwelling. Approaching Taiwan, Fanapi induces a cold wake spreading preferably on the right side of the essentially westward running track in the western Pacific. The three upwelling areas in the East China Sea and Taiwan Strait subsequently become expansive as Fanapi approaches and enters the Taiwan Strait. The mechanisms leading to normal or Fanapi-perturbed upwelling and circulation in seas around Taiwan, especially the latter two mentioned above, are suggested. In essence, Fanapi disrupts circulation in the Taiwan Strait, and also the Taiwan Strait outflow entering the East China Sea, leading to expanded upwelling areas. We also suggest that high-resolution wind and tides application is essential for the upwelling modeling study and also the general circulation in the region with and without typhoons.
\end{abstract}

Key words: Typhoon Fanapi, Typhoon-Ocean interaction, Typhoon induced upwelling

Citation: Ko, D. S., S. Y. Chao, C. C. Wu, I.I.Lin, and S. Jan, 2016: Impacts of tides and Typhoon Fanapi (2010) on seas around Taiwan. Terr. Atmos. Ocean. Sci., 27, 261-280, doi: 10.3319/TAO.2015.10.28.01(Oc)

\section{INTRODUCTION}

Typhoon Fanapi (2010) was originated from a tropical depression over the western North Pacific Ocean far southeast of Taiwan on September 14 (Fig. 1). Later that day the Joint Typhoon Warning Center (JTWC) upgraded the system to a Tropical Storm and named it Fanapi. On September 16 the storm intensified into a typhoon and turned northwest. By September 18 Fanapi further intensified into a category-3 typhoon and moved straight toward Taiwan (Lin et al. 2013; D'Asaro et al. 2014). Fanapi subsequently made its first landfall over Hualien, Taiwan early on September 19. After passing over Taiwan, Fanapi weakened into a tropical storm and made its second landfall over Fujian, China early on September 20. Heavy rainfall caused severe floods in Kaohsiung, Taiwan, and killed over 100 people in Guangdong,

\footnotetext{
* Corresponding author

E-mail:ko@nrlssc.navy.mil
}

China. Under the sponsorship of the US Office of Naval Research and Taiwan's National Science Council, Fanapi was monitored by airborne and seagoing measurements as a part of the ITOP international project (Lin et al. 2013; D'Asaro et al. 2014). The monitoring campaign was particularly intensive in the areas east of Taiwan from $123-129^{\circ} \mathrm{E}$ and $20-26^{\circ} \mathrm{N}$ during Typhoon Fanapi (Mrvaljevic et al. 2013). The acronym ITOP stands for "Impact of Typhoons on the Ocean in the Pacific" in the US and "Internal wave and Typhoon-Ocean interaction Project in the Western North Pacific and Neighboring Seas" in Taiwan.

The freshwater discharge entering the East China Sea (ECS) is known to induce sizable upwelling off the mouth of Changjiang (e.g., Tseng et al. 2013). Aside from the plume-induced upwelling, three patches of summer upwelling under normal conditions stand out in the ECS and Taiwan Strait. The one over the ECS shelf break off northeast 
Taiwan is the most widely known for its intensity, tenacity, biological productivity, and proximity to the Kuroshio (e.g., Liu et al. 1992; Wu et al. 2008; Chang et al. 2009). Northwest of Taiwan and spreading off the Chinese coast there is also a shore-parallel and sometimes fragmented patch of upwelling, the northern part of which is locally known as the Zhejiang coastal upwelling for its proximity to the coastal Zhejiang province of China (e.g., Lü et al. 2007; Lou et al. 2011; Yang et al. 2013). The third upwelling was sometimes considered two separate areas off southwest Taiwan with a little gap in between, one along the western flank and another at the up-channel extremity of the deep Penghu Channel in the southeastern Taiwan Strait (e.g., Hu et al. 2001; Hong et al. 2011). The three upwelling areas were invigorated after the passing of Fanapi, mostly in the form of horizontal expansion. The last two upwelling regions have not been adequately examined in the literature. The upwelling mechanisms leading to their maintenance before and changes after Fanapi require investigation.

\section{OCEAN MODEL}

An ocean modeling system, the East Asian Seas Nowcast/Forecast System (EASNFS) used for this study, is an application of the Naval Research Laboratory (NRL) Ocean Nowcast/Forecast System (Ko et al. 2008). The dynamic ocean model in the EASNFS is the Navy Coastal Ocean Model (NCOM; Martin 2000) developed at NRL and in operation at the Naval Oceanography Office. A statistical regression model, the Modular Ocean Data Assimilation System (MODAS; Carnes et al. 1996; Fox et al. 2002) based on historical observations, is used to produce the three-dimensional ocean temperature and salinity analyses from satellite altimetry and Multi-Channel Sea Surface Temperature. EASNFS then assimilates the analyses by continuous modification of model temperature and salinity toward the analyses using a vertical weighting function that reflects the oceanic temporal and spatial correlation scales and the relative confidence between the model forecasts and analyses. Scale separation is applied in data assimilation to preserve the fast-varying components described in more detail in Ko and Wang (2014).

The EANSFS model domain covers the entire East Asian marginal seas and part of the West Pacific Ocean from $17.3^{\circ} \mathrm{S}$ to $52.2^{\circ} \mathrm{N}$ and from $99.2^{\circ} \mathrm{E}$ to $158.2^{\circ} \mathrm{E}$ (Fig. 1). The horizontal resolution $\left(\sim 1 / 12^{\circ}\right)$ ranges from about $9.8 \mathrm{~km}$ at the equator to about $6.5 \mathrm{~km}$ at the model's northern boundary. It is about $9 \mathrm{~km}$ in the study region. There are 41 sigma-z levels with denser levels in the upper ocean to gain resolution. EASNFS analysis has been previously applied in several studies to the western North Pacific. In seas around Taiwan, it has been applied to investigate the impact of typhoons on the upper ocean temperature (Lin et al. 2008), upwelling off the southern coast of Taiwan (Ko et al. 2009), thermal structures in the South China Sea (Chang et al. 2010), and the impact of eddies on the Kuroshio transport along the east coast of Taiwan (Lee et al. 2013).

In conjunction with atmospheric forcing to be described

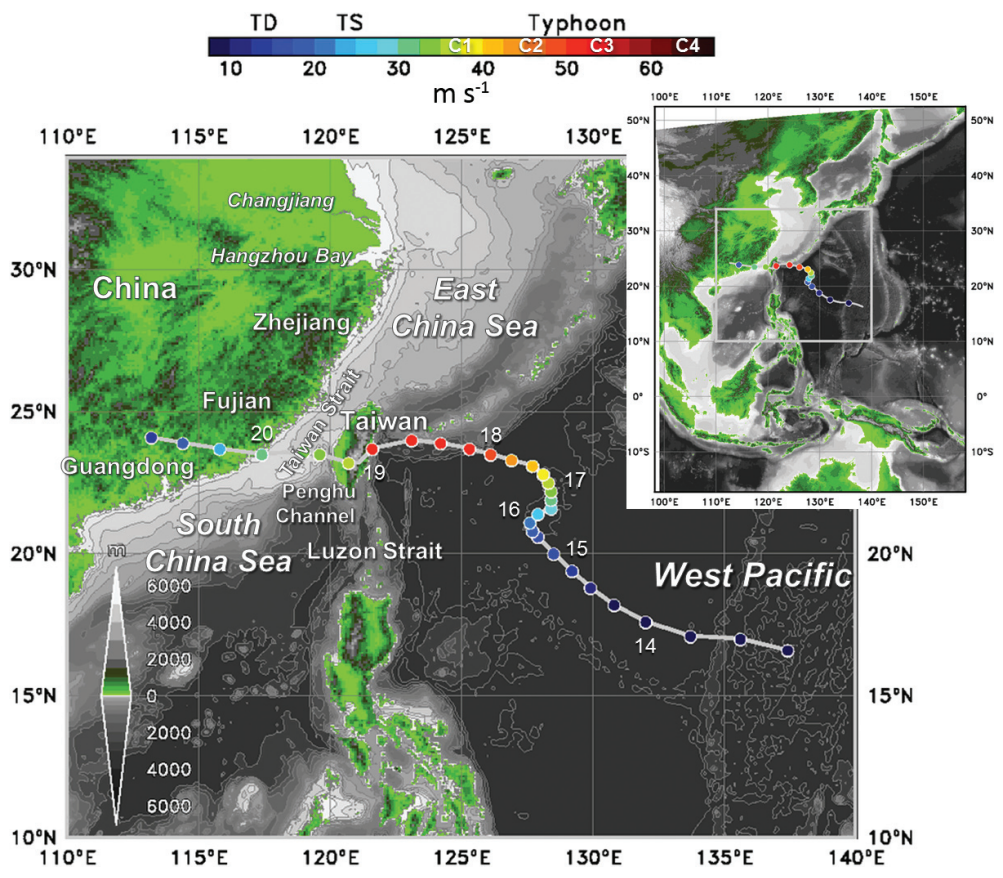

Fig. 1. EASNFS model domain with topography and an inset covered by WRF model in the top-right panel. Typhoon Fanapi's track (from JTWC best-track) is shown in the main panel over the WRF domain is dotted 6-hourly with color indicating 1-minute maximum sustained wind speed and the equivalent Saffir-Simpson hurricane wind scale. Numbers along the track date the center of typhoon. 
in the next section (section 3), EASNFS also implemented river forcing and astronomical tides. Inside the model domain 142 rivers derived from the World Meteorological Organization (WMO) Global Runoff Data Center archives were released with monthly climatologic mass flux, temperature and zero salinity from their respective river mouths. Tides authenticate storm surge assessment. Our preliminary numerical experiments also pointed out the importance of tides to enhance upwelling in seas around Taiwan and cold wake formation behind Fanapi. For these reasons we included eight tidal constituents $\left(\mathrm{K}_{1}, \mathrm{O}_{1}, \mathrm{P}_{1}, \mathrm{Q}_{1}, \mathrm{~K}_{2}, \mathrm{M}_{2}, \mathrm{~N}_{2}\right.$, and $\left.\mathrm{S}_{2}\right)$ obtained from the Oregon State University Tidal Prediction Software (Egbert and Erofeeva 2002).

\section{ATMOSPHERIC FORCING ENHANCEMENT}

We derive the atmospheric forcing from high-resolution Weather Research and Forecasting (WRF) model outputs, supplemented with Navy Operational Global Atmospheric Prediction System (NOGAPS; Rosmond 1992) products. The WRF model domain (inset in Fig. 1) runs on a triple $(54 / 18 / 6 \mathrm{~km})$ nested grid system with finer interior grids moving with Fanapi to gain resolution. By applying the ensemble Kalman filter method, as used in $\mathrm{Wu}$ et al. (2010, 2012), the WRF model assimilated Fanapi's track from JTWC, SFMR (Stepped Frequency Microwave Radiometer), and dropsonde winds from both C-130 and Astra (DOTSTAR; Wu et al. 2005) aircraft made by US and Taiwan participants during the 2010 typhoon-tracking ITOP experiment. The $10 \mathrm{~m}$ wind and sea level air pressure from WRF are interpolated onto the ocean model grid in areas covered by the triple nested grid and meshed with predictions from NOGAPS in areas outside.

To cope with typhoon level winds the wind stress vector $(\vec{\tau})$ is related to air density $\left(\rho_{a}\right)$ and $10-\mathrm{m}$ wind vector $(\vec{u})$ with a dimensionless drag coefficient $\left(C_{d}\right)$ as $\vec{\tau}=\rho_{a} C_{d}|\vec{u}| \vec{u}$, where $C_{d}$ follows the formulation of Large et al. (1994) but levels off abruptly once the wind speed exceeds $30 \mathrm{~m} \mathrm{~s}^{-1}$ as suggested by Donelan et al. (2004). Of more relevance to typhoon-induced Ekman pumping and cold wake development is the wind stress curl $(\nabla \times \vec{\tau})$, which is a higher order variable critically sensitive to the weather forecast model resolution. With fine-resolution moving grids and data assimilation the underestimation of wind stress curl is largely overcome by the WRF model. For example, at 1200 UTC September 18, the WRF model was able to enhance NOGAPS wind stress curl around Fanapi more than eightfold (Fig. 2).

In general, NOGAPS wind can resolve broader scale wind fields reasonably well. In the eye wall proximity, however, it is essential to use WRF model winds to bring up the wind intensity closer to the observed level. By doing so the EASNFS's skill is vastly improved near the typhoon track where cold wake develops. Away from Fanapi's track the ocean's response remains essentially unchanged under either WRF or NOGAPS winds. To clarify this point before our main discussions on ocean responses, Fig. 3 shows instantaneous Sea Surface Temperature (SST) and ocean surface currents at 0000 UTC September 19, driven by WRF winds in Fig. 3a and NOGAPS winds in Fig. 3b. Tidal forcing was included in both. At this time Fanapi was just about to make landfall over Taiwan. Using WRF winds the cold wake and internal inertial current are markedly enhanced near Fanapi (Fig. 3a) over the western North Pacific. The cold wake agrees with the 8-day averaged composite satellite microwave SST observations centered at 19 September 2010 in Fig. 3c. In our area of interest Fanapi was initially stagnant but increased its translation speed to about $4 \mathrm{~m} \mathrm{~s}^{-1}$ after turning to west. The speed further accelerated to about $8 \mathrm{~m} \mathrm{~s}^{-1}$ at the time of landfall over Taiwan. This pronounced cold wake over the western North Pacific of $\sim 26^{\circ} \mathrm{C}$ in Fig. $3 \mathrm{c}$ was found to be associated with a shallower subsurface warm layer and modest translation speed during Fanapi's passing (Lin et al. 2013; Mrvaljevic et al. 2013). It can be
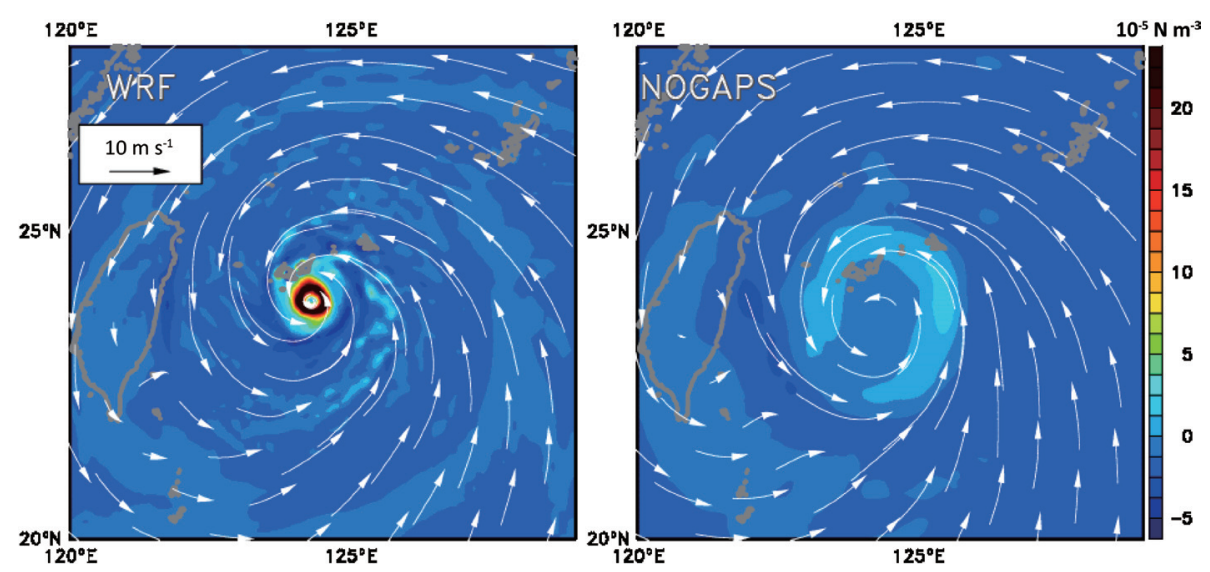

Fig. 2. Wind stress curl in color and 10-m wind in vector at 1200 UTC 18 September 2010 produced by WRF model (left panel) and NOGAPS (right panel). 

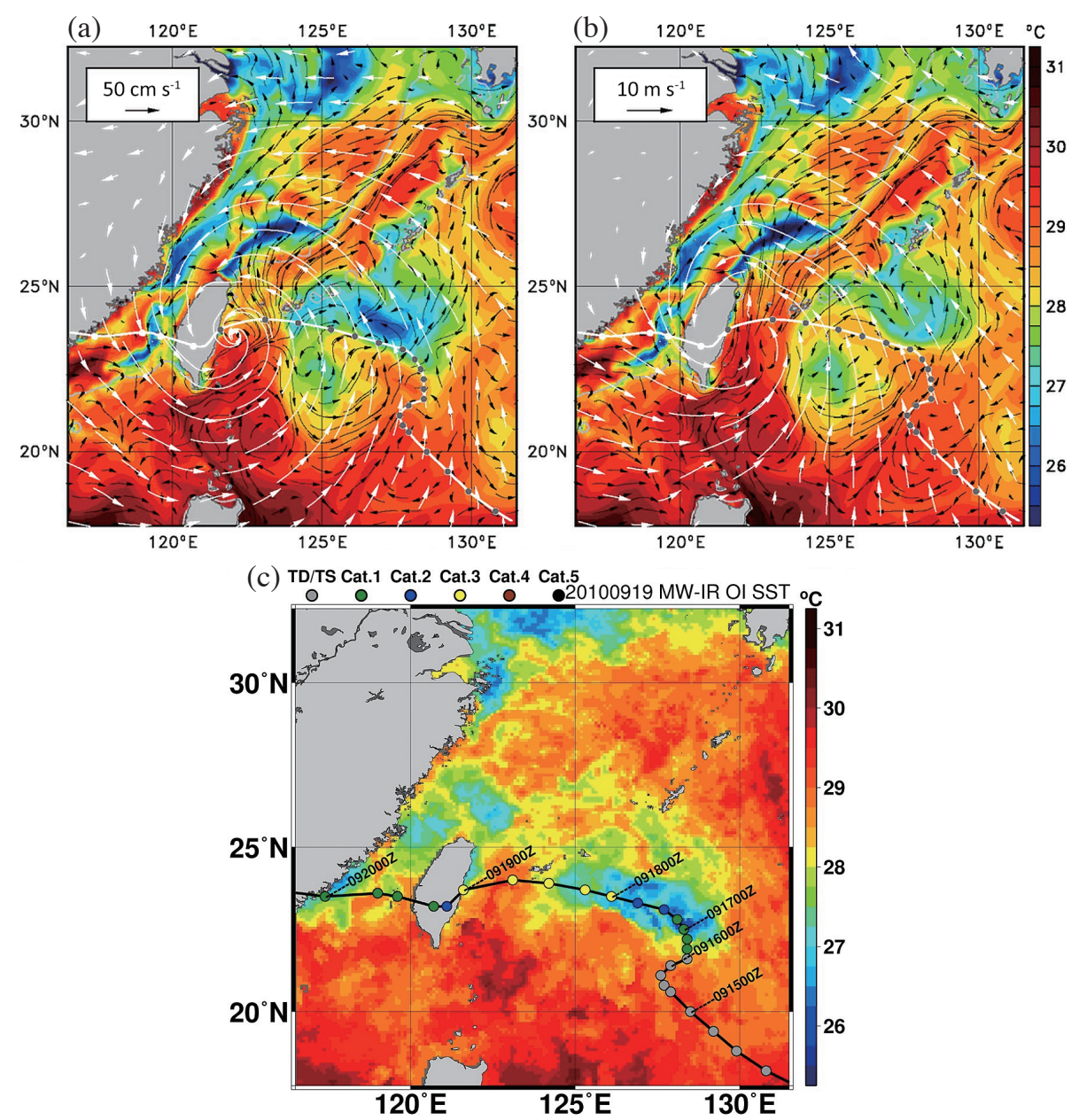

Fig. 3. Instantaneous SST and sea surface currents (in black arrows scaled in top-left) with tidal forcing included at 0000 UTC 19 September 2010 driven by winds (in white arrows scaled in top right) from (a) WRF and (b) NOGAPS, along with (c) concurrent 8-day composite SST derived from satellite observations. Superimposed is JTWC best-track for Fanapi dotted six-hourly.

seen that the NOGAPS wind forcing is too weak to produce this feature (Fig. 3b). In contrast, the WRF atmospheric forcing can produce this cold wake more realistically (Fig. 3a). The model also produces a weak, transient cold water area centered at $23^{\circ} \mathrm{N}$ and $125^{\circ} \mathrm{E}$ (Figs. $3 \mathrm{a}$ and b), observed and attributed to cold wake advection by a cyclonic circulation by Mrvaljevic et al. (2013). The composite satellite SST image (Fig. 3c) reduces the intensity of this feature because of the 8-day averaging.

Away from the track (in ECS and Taiwan Strait) features such as the three patches of upwelling remain largely the same under either WRF winds (Fig. 3a) or NOGAPS winds (Fig. 3b). In Fig. 3c, the composite SST image shows much diffused cold wakes because of time averaging.

Figure 4, derived from the WRF model, shows daily $10 \mathrm{~m}$ wind and sea level air pressure before, during and after Fanapi's transit over the Taiwan Strait. Fanapi weakened after the first landfall over Taiwan, weakened further over the Taiwan Strait and dissipated eventually after the second landfall over China (Fig. 1). The front end precursor of Fa- napi was long. At September 17, before Fanapi approached Taiwan, the northeast wind ranging in excess of $10 \mathrm{~m} \mathrm{~s}^{-1}$ had already been developing over the ECS and Taiwan Strait. Fanapi's arrival at Taiwan brought strong cyclonic winds over the whole region. Wind diminished quickly after Fanapi made landfall over China.

The simulation with improved atmospheric forcing, including 10-m wind and sea level air pressure, was conducted from 1 September to 1 October 2010 for one month period that includes Typhoon Fanapi. Prior to September the simulation was done with NOGAPS forcing.

\section{NORMAL UPWELLING BEFORE FANAPI}

Figure 5 shows modeled SST and sea surface currents on 12 September 2010, well before Fanapi became a tropical depression. Both are de-tided using a 42-h low-passed filter. Winds at this time were weaker than $5 \mathrm{~m} \mathrm{~s}^{-1}$ everywhere and therefore not shown. On the open ocean side, one sees the Kuroshio flowing northward, past Luzon Strait 


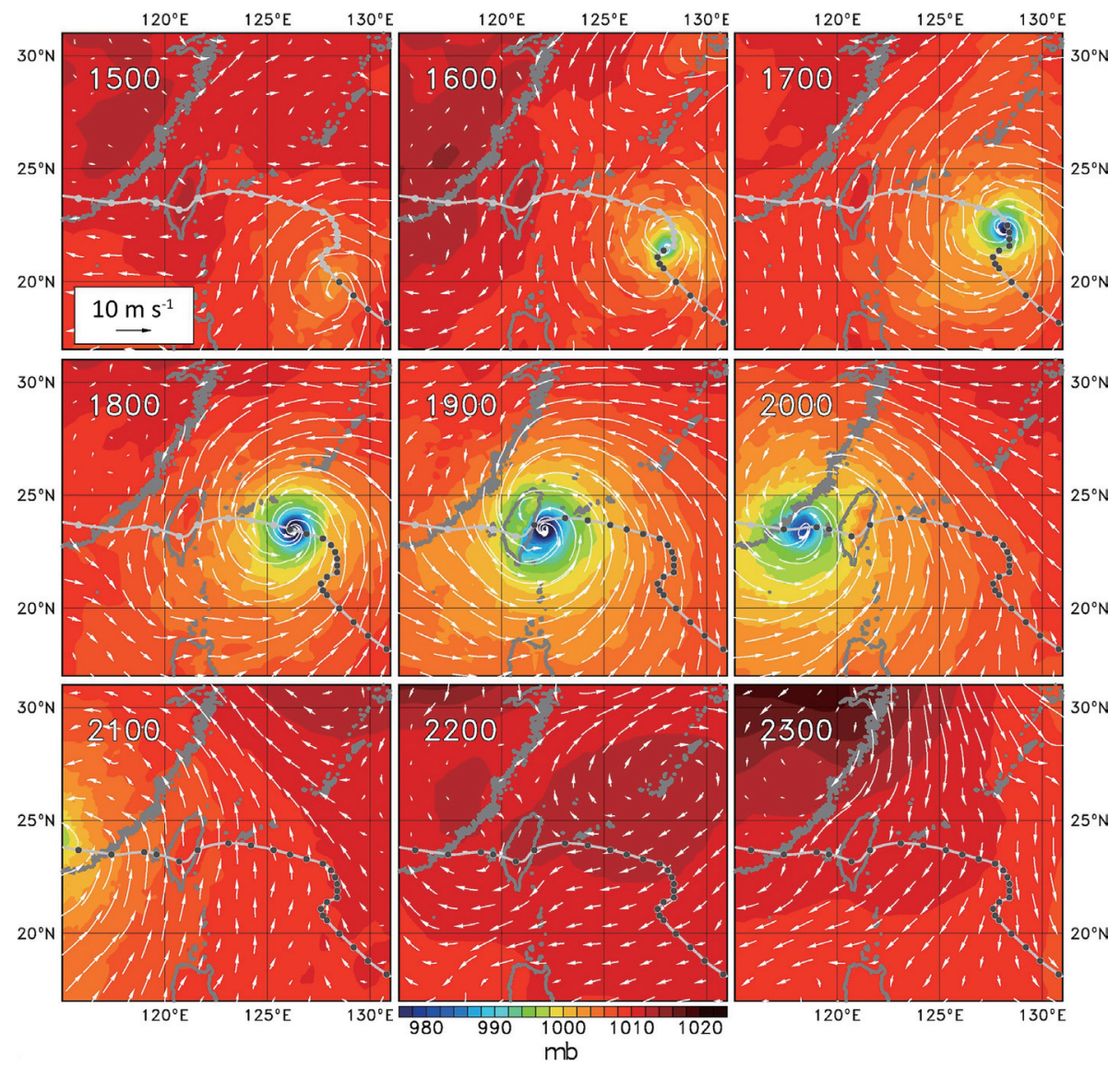

Fig. 4. From left to right and top to bottom: daily snapshots of atmospheric forcing (10-m wind vector and sea level air pressure in color) from 0000 UTC 15 September 2010 (about 4 days before Fanapi's landfall over Taiwan) to 0000 UTC 23 September 2010 (about 3 days after Fanapi's landfall over China). The JTWC track is superimposed.
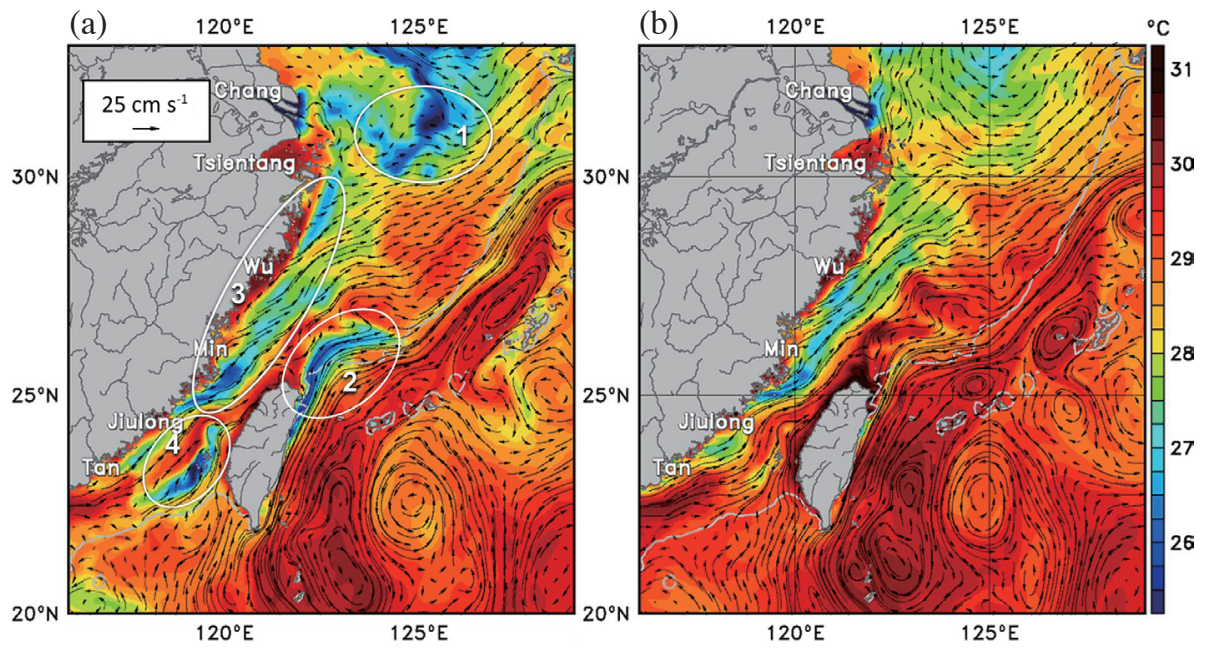

Fig. 5. The 42-h low-passed SST and ocean surface currents (black arrows) at 0000 UTC 12 September 2010, well before Fanapi became a tropical depression: (a) with tidal forcing and (b) without tidal forcing. Four upwelling regions 1, 2, 3, and 4 are enclosed by ellipses in (a). Also marked are model-imposed river forcing locations. 
and along the east coast of Taiwan and shelf break of ECS. Seaward of the Kuroshio are densely packed eddies. These open ocean features are not our major concern in this study despite their potential impact on the cold wake and typhoon intensity (e.g., Lin et al. 2008). To help identify upwelling mechanisms in the seas around Taiwan, the corresponding model result without tidal forcing is also shown in the right panel (Fig. 5b). In the simulation with tides (Fig. 5a) four patches of upwelling stood out. The northernmost one was off Changjiang runoff (region 1 in Fig. 5a). The other three were located off northeast Taiwan (region 2), northwest of Taiwan (region 3), and southwest of Taiwan (region 4). Comparing Figs. 5a and b, it is clear that all four patches of upwelling are enhanced by tides. Among the four, the one including Zhejiang coastal upwelling and its southward extension northwest of Taiwan (region 3) requires the least help from tides to show up.

Upwelling off northeast Taiwan (region 2) arises from the Kuroshio impingement onto the shelf break. Literature on this phenomenon is rather extensive (e.g., Liu et al. 1992; Wu et al. 2008; Chang et al. 2009; Jan et al. 2011; Gopalakrishnan et al. 2013) and our discussion will be abbreviated. The upwelling is induced mostly by orographic lifting of the Kuroshio. As the Kuroshio impinges onto the shelf the bottom Ekman flow lifts the cold water along the slope up to the shelf. As the Kuroshio is deflected seaward, to conserve potential vorticity sea level becomes lower in the void region. Upwelling occurs together with a cyclonic circulation to fill part of the low pressure (Wu et al. 2008). Tidal enhancement is also conceivable because on-shelf tidal current is also lifted in half of a tidal cycle, contributing to upwelling. Further, tidal mixing de-stratifies the water column, allowing upwelled cold water to move up the water column farther.

Zhejiang coastal upwelling and its southward extension (region 3) have been of recent interest (e.g., Lü et al. 2007; Lou et al. 2011; Yang et al. 2013). Satellite images sometimes showed disjointed patches of upwelling in this belt (e.g., Lou et al. 2011). Figure 3c is another example. At the latitude of the northern limit of the Taiwan Strait an upwelling patch off the China coast, locally known as the Pingtan upwelling (Hong et al. 2011), may also be integrated as part of this belt in our view.

Figure 5 offers only a glimpse of this upwelling belt (region 3 ) among numerous variations. At this time concurrent sea surface salinity (not shown) showed parcels of brackish waters shoreward of this upwelling belt. Their locations coincided with a strip of warm waters between the coastline and upwelling belt in Fig. 5. The EASNFS implemented all sizable rivers ranging from small to major with monthly climatology runoff. From north to south the climatology September runoff temperature is $24.4^{\circ} \mathrm{C}$ from Changjiang, $25.9^{\circ} \mathrm{C}$ from Tsientang River, $27.7^{\circ} \mathrm{C}$ from Wu River, $27.0^{\circ} \mathrm{C}$ from Min River, $26.0^{\circ} \mathrm{C}$ from Jiulong River, and $27.2^{\circ} \mathrm{C}$ from Tan River. The coastal band of brackish water is about $1-2^{\circ} \mathrm{C}$ warmer, apparently enhanced by September sensible heat flux under the calm wind condition. As we will see later in Figs. 6 and 7 the coastal band of warm and brackish water remains largely intact even under modest wind conditions during Fanapi's passage. Winds during Fanapi are mostly from the moist-laden open ocean environment (Fig. 4) and therefore unable to evaporate. The anticipated lack of latent heat loss is expected to preserve the warm anomaly.

The mechanisms leading to the Zhejiang coastal upwelling were analyzed recently in two numerical models (Lü et al. 2007; Lee et al. 2014). Lü et al. (2007) attributed this upwelling to tides. Even in homogeneous water bottom convergence and shoreward shoaling of tidal residual current may produce this upwelling. On the other hand, the upwelling can be induced by the cyclonic vorticity on the shoreward side of the Taiwan Strait Current and tidal residual current can enhance this upwelling (Lee et al. 2014). The mechanism will be reexamined in section 8 .

Summer upwelling near the Penghu Channel southwest of Taiwan (region 4) was also documented (e.g., Hu et al. 2001; Hong et al. 2011). Past observations (e.g., Hu et al. 2001), mainly derived from satellite images, often distinguished the northern extremity of this upwelling (known as the Penghu Island upwelling) from the nearby upwelling along the left banks of the Penghu Channel (known as Taiwan Banks upwelling). In our view the gap may be too small to divide the two. Inflow from the Penghu Channel feeds most of the Taiwan Strait Current (Jan et al. 2002a). The northward current uplifted by the shoaling channel bottom could conceivably induce upwelling over the northern end of the Penghu Channel. Over the west flank of Penghu Channel the bottom Ekman flow is westward, upslope and expected to induce upwelling. Upslope water movement must overcome stratification and is anticipated to be weak in the absence of tides (Fig. 5b). Tidal currents, barotropic and baroclinic alike, lift and mix cold waters with surface waters in half of an irreversible tidal cycle because downwelling in another half of the tidal cycle cannot return surface waters to the premixed condition. In essence tidal mixing de-stratifies the water column, aiding upwelling along the slope. Figure 5 offers an explanation of why this upwelling came to light in numerical models mostly after tides were included (also Hong et al. 2011).

Tidal enhancement of the Changjiang plume upwelling (region 1) is off our scope for its remoteness from $\mathrm{Fa}$ napi and had been examined in numerical models (Wu et al. 2011; Lee et al. 2014). In general, tides enhance offshore detachment and southward dispersion of the plume to some extent. Conceivably, they also enhance plume-induced upwelling as seen in Fig. 5a.

\section{UPWELLING DURING FANAPI}

According to JTWC best-track (Fig. 1), Fanapi was 

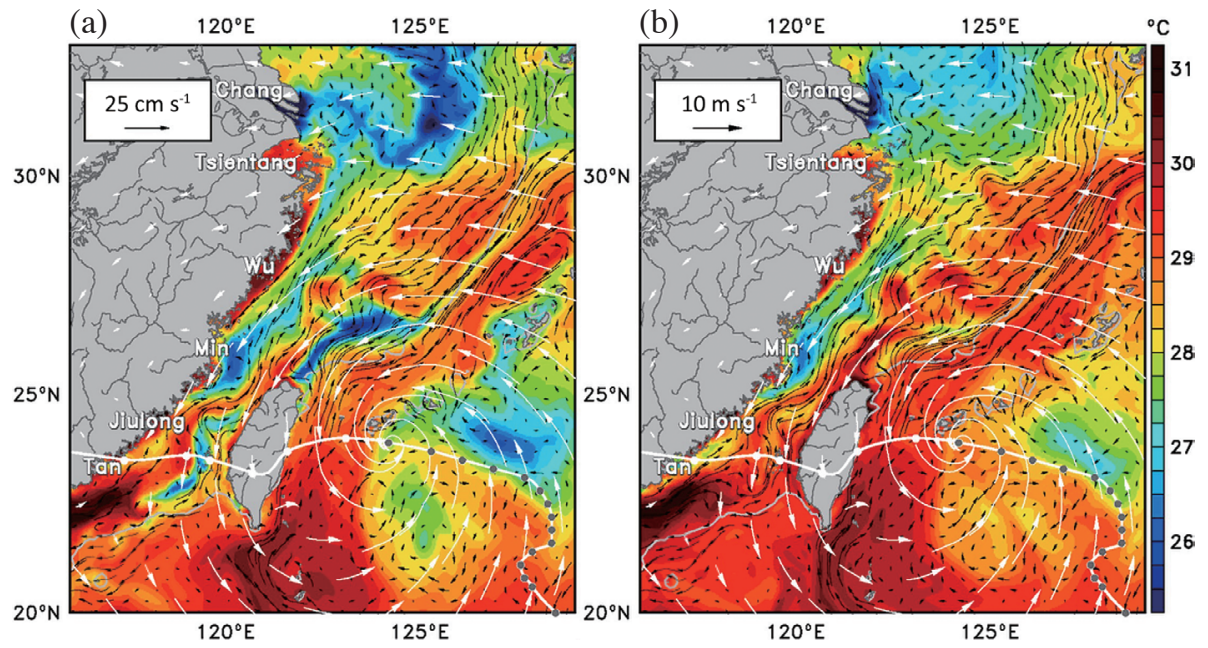

Fig. 6. (a) Depth-averaged, 42-h low-passed ocean current in black arrows (scaled in top left panel) and 42-h low-passed SST with tidal forcing at 1200 UTC 18 September 2010, with JTWC's best-track dotted six-hourly. (b) Corresponding features without tidal forcing. Also marked are modelimposed river forcing locations and $10 \mathrm{~m}$ wind in white arrows (scaled in top right panel).
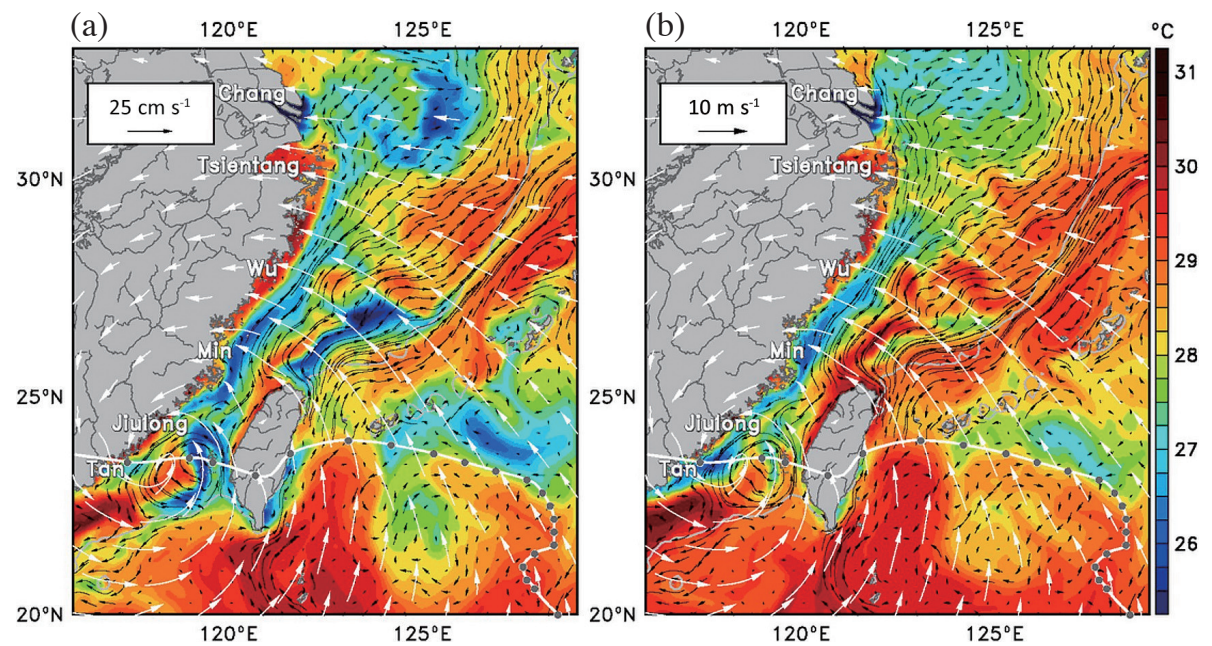

Fig. 7. Same as Fig. 6 except at 0000 UTC 20 September 2010 when Fanapi was over the Taiwan Strait (a) with tides and (b) without tide.

relatively stagnant over the western North Pacific before turning west on 17 September 2010. Figure 8 shows the translation speed of Fanapi as a function of time. It increased to about $4 \mathrm{~m} \mathrm{~s}^{-1}$ after turning and further increased to about $8 \mathrm{~m} \mathrm{~s}^{-1}$ at the time of landfall over Taiwan. The $4 \mathrm{~m} \mathrm{~s}^{-1}$ mark may be used as a rough criterion to measure the degree of rightward bias for the cold wake, which becomes markedly visible if the translation speed exceeds the threshold (Price 1981; Zedler 2009).

At 1200 UTC September 18 Fanapi was approaching Taiwan. Figure 6 shows the 42-h low-passed SST and depth-averaged, 42-h low-passed ocean currents with tidal forcing in Fig. 6a and without tidal forcing in Fig. 6b. While the low-pass filter de-tides, depth averaging is meant to remove most of the open ocean features. Around September
18 the prevailing northeast downwelling-favorable wind before Fanapi (Fig. 4) was unable to stop the northeastward Taiwan Strait Current over the ESC in the depth-averaged sense. In Fig. 6 the downwind, southward coastal jet was narrowly confined along the southeast coast of China. Offshore of it was the prevailing northeastward Taiwan Strait Current. The cyclonic current shear between the nearshore downwind coastal jet and northeastward Taiwan Strait Current provokes mid-shelf upwelling off southeast China. This issue about mid-shelf upwelling off southeast China will be discussed from a wider perspective in section 8. In addition to the three patches of upwelling in the seas around Taiwan, a cold wake followed Fanapi with rightward bias as one would expect from a typhoon moving faster than $4 \mathrm{~m} \mathrm{~s}^{-1}$ (Price 1981; Zedler 2009). At this time the 
northeasterly winds far west of Fanapi had become sufficiently strong over the ECS and Taiwan Strait (Fig. 4). Relative to the simulation without tidal forcing (Fig. 6b), all three patches of upwelling in seas around Taiwan and the cold wake were visibly enhanced by tides (Fig. 6a). Between the upwelling off southeast China and the coast, the warm and narrow runoff-driven coastal boundary layer persisted from the wide and long embayment centered at $30^{\circ} \mathrm{N}$ (Hangzhou Bay) southward. With or without tides, the onshelf Kuroshio waters intrusion was enhanced at this time, most of which turned northward over ECS. As we will see later in section 7 this was the time the Taiwan Strait Current was about to be stopped by the northeast wind.

Relative to Fig. 6 the nearly contemporaneous satellitederived SST image (Fig. 3c) showed three upwelling areas in a different light. Referring to upwelling areas enumerated in Fig. 5a, upwelling off the northeast Taiwan (region 2) showed up weaker but wider in satellite observations (Fig. 3c) mostly because the composite satellite image is after time averaging. Upwelling off southeast China (region 3) became fragmented in Fig. 3c. Zhejiang coastal upwelling centered along $30^{\circ} \mathrm{N}$ (off the long and wide embayment, Hangzhou Bay in Fig. 3c) came out highly visible relative to the model-produced. The middle reaches of upwelling off southeast China in Fig. 3c became visibly connected with upwelling off northeast Taiwan. Conceivably, the composite satellite image is essentially a time-averaged product that the model cannot exactly mimic. The lower reaches (in the northern Taiwan Strait) expanded to cover the entire width of the Strait. Between the upwelling belt off southeast China and the coastline the coastal strip of warm waters related to freshwater runoff also showed up in Fig. 3c, consistent with the model-produced SST in Figs. 6a or b. Penghu Channel upwelling (region 4) came out smaller and weaker in Fig. 3c than the model-produced in Fig. 6a. A band of coastal upwelling on the Chinese side of the southern Taiwan Strait became much more visible than the model-produced, apparently driven by local seaward wind at the time (Figs. 3a or 4). Satellite-derived SST came from different methodology and time averaging to fill data gaps. The surface layer thickness in EASNFS, $1 \mathrm{~m}$ in deep ocean, though thinner on the shallow water due to sigma-coordinates over the shelf, may not exactly replicate sea surface conditions. For example, under calm winds and less cloudy conditions, the warm skin layer often masks upwelling from detection by satellite-borne sensors. The skin layer aside, the overextended time (8-day) averaging that resulted in the composite satellite SST image (Fig. 3c) is always a prominent source of model-data discrepancy. The strong showing of the Zhejiang coastal upwelling in satellite SST on September 19 (Fig. 3c) might have also come from deviation of Qiantang River runoff from prescribed monthly climatology in our model. These complexities put the model-data discrepancies in perspective.

By 0000 UTC on September 20 Fanapi had entered the
Taiwan Strait. Figures 7a and b show the concurrent, instantaneous $10 \mathrm{~m}$ wind, 42-h low-passed SST and 42-h lowpassed and depth-averaged ocean current with and without tidal forcing, respectively. The three patches of upwelling in seas around Taiwan still persisted and generally became more expansive, and tidal enhancement continued to be active. The on-shelf intrusion of Kuroshio waters continued. Relative to Fig. 6 the depth-averaged Taiwan Strait Current was regaining strength. On the deep ocean (east) side of Taiwan the cold wake on the right hand side of Fanapi track generated 2 days earlier were still vigorous but slowly dissipating. In addition, a narrow band of upwelling along the southeastern coast of Taiwan showed up, in keeping with the prevailing upwelling-favorable wind at the time. Tides also enhanced this coastal upwelling. With or without tides, massive on-shelf intrusion of Kuroshio water still took place over ECS at this time. As we will re-verify later in section 7 the continued blocking of the Taiwan Strait Current by Fanapi sustained this massive on-shelf intrusion. Off southeast China the upwelling belt (region 3 in Fig. 5a) under the influence of massive Kuroshio intrusion from northeast of Taiwan and weaker-than-normal Taiwan Strait Current (Fig. 7) persisted.

The massive onshore intrusion with Fanapi deserves a little more discussion. Under normal conditions with calm winds the Kuroshore intrusion is restricted to the region off northeast Taiwan slightly shoreward of the $200 \mathrm{~m}$ isobath (the shelf break). With Fanapi the onshore Kuroshio intrusion reaches far beyond, almost to the inner shelf off southeast China shallower than $50 \mathrm{~m}$ whether tides are included or not (Figs. 7a and b). In terms of SST, tidal forcing contributes greatly to the upwelling at this time of massive onshore Kuroshio intrusion (Fig. 7a). Without tidal forcing, the cold dome induced by upwelling off northeast Taiwan weakens considerably (Fig. 7b).

Fanapi Translation Speed

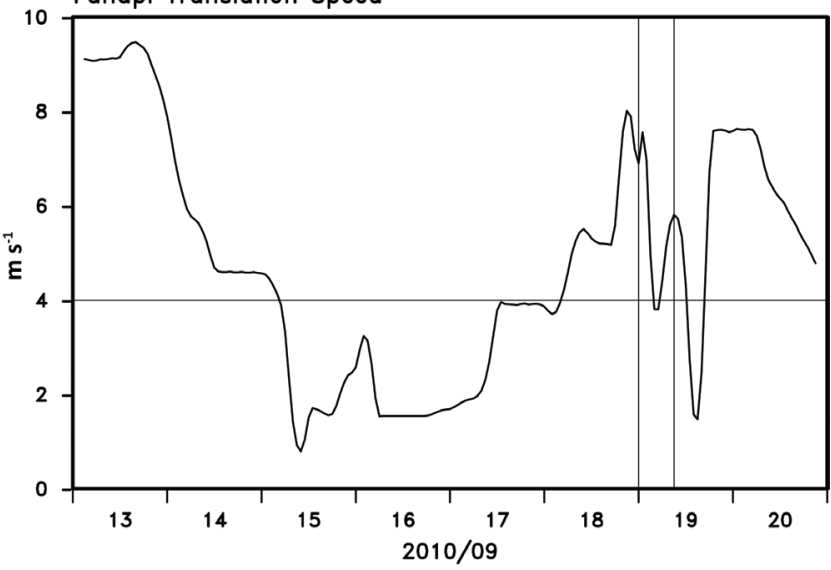

Fig. 8. Typhoon Fanapi's transition speed estimated from JTWC besttrack with two vertical lines indicating its landfall over and subsequent departure from Taiwan. 


\section{SEA LEVEL}

We include this section mainly to explain why massive onshore Kuroshio waters intrusion occurred from northeast of Taiwan during Fanapi. In essence, Fanapi stopped the Taiwan Strait Current, reduced the water supply to the ECS from the Taiwan Strait, and consequently decreased the Sea Surface Height (SSH) over the southern ECS. The consequent shoreward pressure gradient force invited the Kuroshio to intrude farther shoreward from northeast of Taiwan. The following discussion bears this out.

Tidal propagation in seas around Taiwan has been investigated extensively (e.g., Lefèvre et al. 2000; Jan et al. 2002b; Niwa and Hibiya 2004) and is not our focal point. Rather, to unmask Fanapi-induced SSH variations, Fig. 9 shows daily close-ups of de-tided SSH and depth-averaged ocean currents in the seas around Taiwan before and after Fanapi entered the Taiwan Strait. De-tided storm surge is reduced in amplitude; the instantaneous storm surge riding on oscillating tides could be much higher. The $10-\mathrm{m}$ winds are also included as white arrows in Fig. 9, along with Fanapi's track. Fanapi was fast moving $\left(\sim 8 \mathrm{~m} \mathrm{~s}^{-1}\right)$ when approaching Taiwan (Fig. 8). The north-south extent of Taiwan's east coast is short relative to the barotropic deformation radius and borders deep water. The storm surge is expected to be modest. In contrast, China's coast is long and borders shallow waters. Although the translation speed was also about $8 \mathrm{~m} \mathrm{~s}^{-1}$ as Fanapi made the second landfall over China (Fig. 8), the storm surge is expected to be larger. Our model results bear out these basic gravity wave properties.

At 0000 UTC September 18 before Fanapi's arrival the background setting (Fig. 9a) showed high sea level over deep waters (western Pacific and Penghu Channel) in geostrophic support of the Kuroshio and Taiwan Strait Currents. By comparison, the ECS and shallow reaches around Taiwan were characterized by low SSH. At this time Fanapi was still one day away from making a landfall over Taiwan. Nevertheless, the would-be northward Taiwan Strait Current was somewhat weakened by northerly winds far ahead (west) of Fanapi in the upper water column in the Taiwan
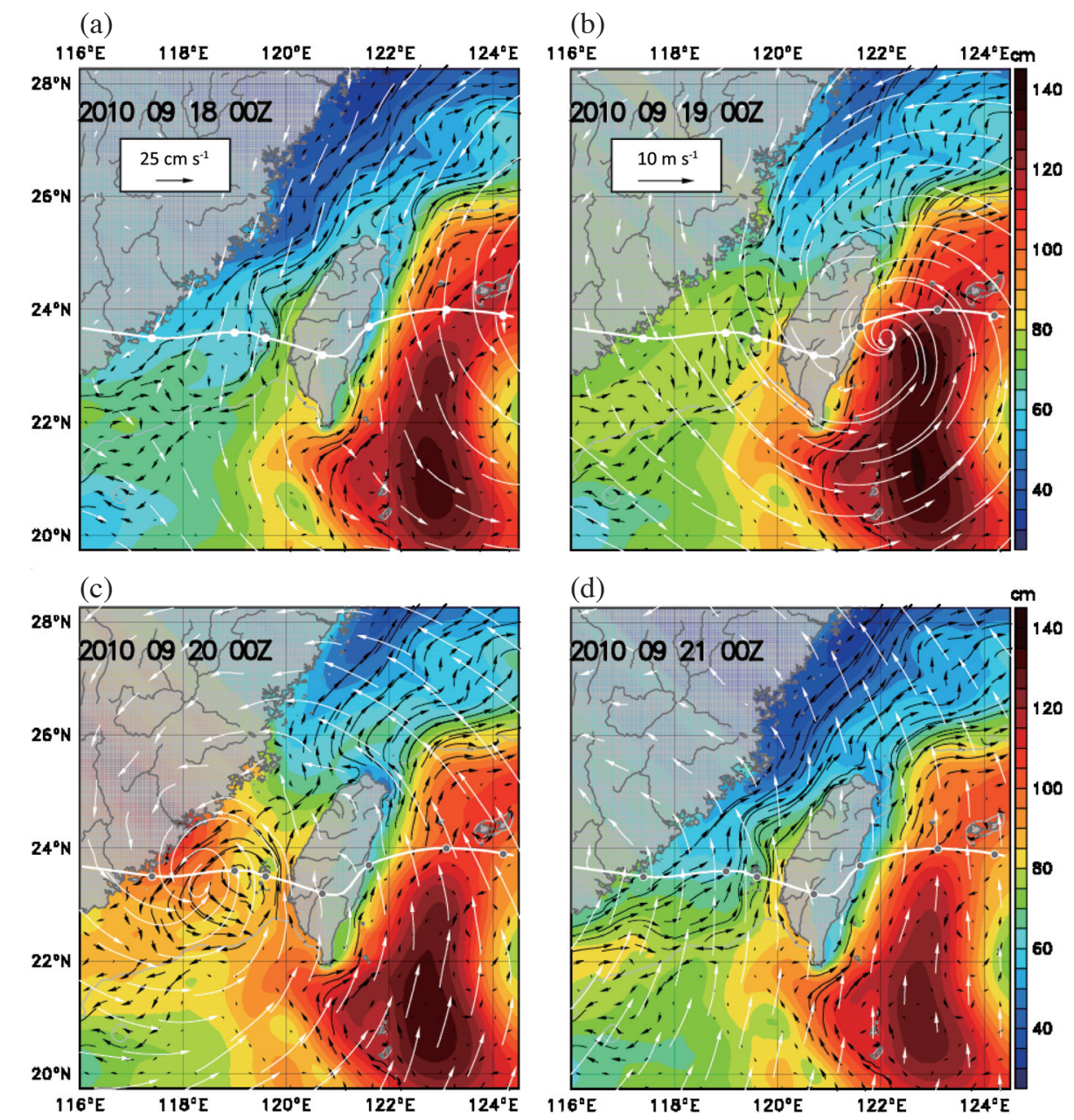

Fig. 9. Daily close-ups of 42-h low-passed EASNFS SSH (in colors) and depth-averaged current (in black vectors) before, during and after Fanapi's transit over the Taiwan Strait at 0000 UTC on (a) September 18, (b) September 19, (c) September 20, and (d) September 21 of 2010 along with JTWC best-track dotted every $6 \mathrm{~h}$ and wind vectors (in white arrows) from WRF model. Ocean current and wind scales are in (a) and (b), respectively. 
Strait (Fig. 9a). The partial blockage of the Taiwan Strait Current reduced an important water supply to the ECS, and SSH was visibly low in areas northwest of Taiwan despite prevailing downwelling favorable winds that were supposed to raise coastal sea level.

As Fanapi made the first landfall over Taiwan around 0000 UTC September 19 (Fig. 9b), the de-tided SSH rose concurrently off east Taiwan. At this time northerly winds well ahead of Fanapi continued to block the northward Taiwan Strait Current in the upper ocean for the second day to the point of reversal and in the process piled up a high SSH reservoir mainly over the Penghu Channel (off southwest Taiwan). The sustained choking maintained an expansive region of low SSH in the northern Taiwan Strait and ECS. Understandably, the Kuroshio water began to intrude onto the ECS and even northern Taiwan Strait from northeast of Taiwan to fill part of the void (Fig. 9b).

At 0000 UTC September 20 as Fanapi was making the second landfall over southeast China (Fig. 9c), the detided SSH rose by as much as $80 \mathrm{~cm}$ over the southwestern reaches of the Taiwan Strait (the so-called Taiwan Banks). At this time the southern half of the Taiwan Strait is in a highly ageostrophic state. The Taiwan Strait Current choking by northeasterly winds and storm surge due to landfall over China built up high SSH over Penghu Channel and Taiwan Banks. Together, they formed a high anomalous blob. The ocean was still locked in a state of Fanapi-driven cyclonic circulation, which was in odd coexistence with the anomalous high. The odd pair, anomalous high and cyclonic circulation in the lower half of Taiwan Strait, essentially blocked the flow or mass exchange between Taiwan Strait and northern South China Sea.
With the relaxation of northerly winds and storm surge disappearance off southeast China the would-be Taiwan Strait Current was no longer held back. By 0000 UTC September 21 (Fig. 9d) the dissipating Fanapi was well inland in China and the Taiwan Strait Current resumed in a fullscale rebound. Its seaward deflection after exiting the Taiwan Strait caused the SSH to drop more on its landward side. Thus the Taiwan Strait Current choking affected the SSH over the ECS profoundly and also invited Kuroshio intrusion onto ECS and Taiwan Strait. Dynamically, as the Taiwan Strait Current weakens or ceases, the SSH over the southern ECS drops because of the reduced water supply from the Taiwan Strait. The shoreward sea surface pressure gradient force is expected to increase concurrently, inviting the Kuroshio water northeast of Taiwan to intrude farther shoreward. As Fanapi began to dissipate well after landfall over China (Fig. 9d) the storm surge disappeared rather quickly in conjunction with the disappearing blockage between the southern Taiwan Strait and northern reaches of the South China Sea. Lower SSH re-established in the Taiwan Strait and the SSH depression northwest of Taiwan (due to seaward deflection of the Taiwan Strait Current) and associated upwelling were returning to normal.

Approaching Taiwan and China the fast-moving Fanapi did not stay long enough to build up damaging storm surges. Figure 10 compares the simulated SSH with those derived from tide gauges at three selected stations along the east coast of Taiwan. To minimize storm surge amplitude damping due to low-pass filtering, the time window of the Lanczos taper for filtering was reduced from our commonly used 42 to $24 \mathrm{~h}$. In general, the model-data agreement is fairly good with correlation coefficient ranging from 0.70 to 0.85 .
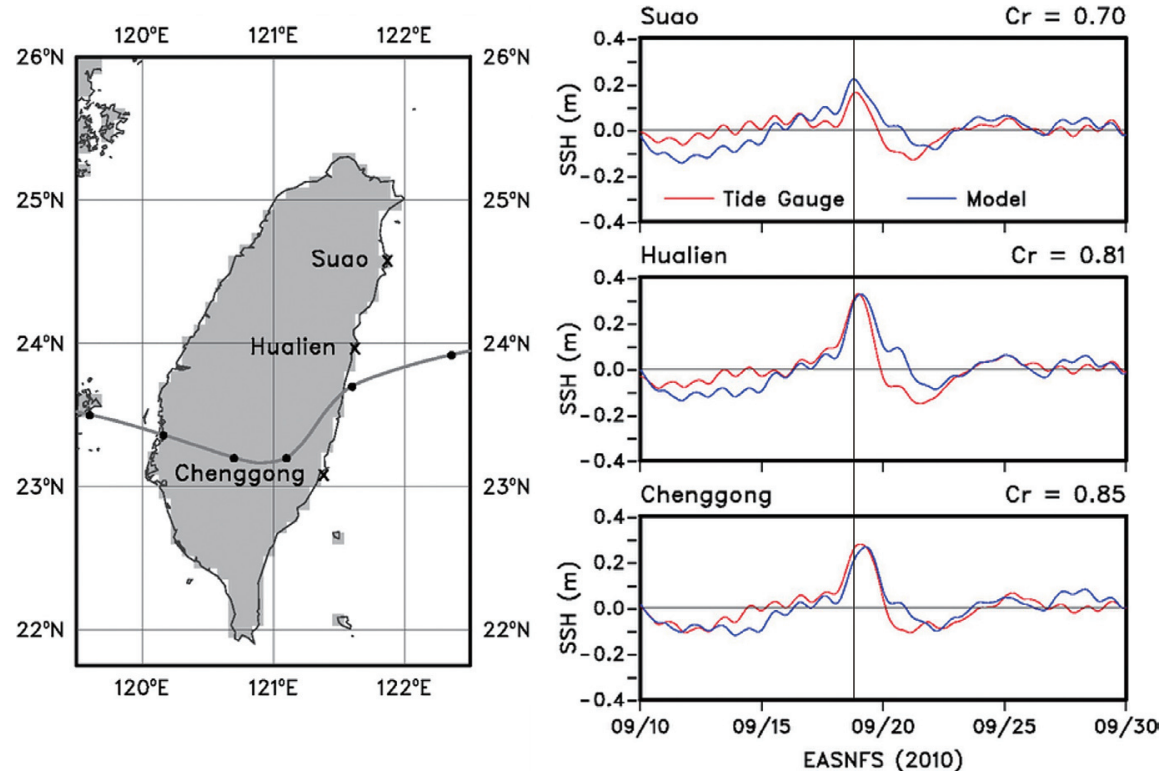

Fig. 10. Model-data comparison of SSH time series after low-pass filtration with a 24-h Lanczos taper at Suao, Hualien, and Chenggong stations from north to south along east coast of Taiwan. The dotted line is the JTWC best-track and Hualien was close to the location of landfall. 
The low-passed storm surge ranged up to $35 \mathrm{~cm}$ with the highest value at the middle station (Hualien), nearest to the location of Fanapi's landfall. The relaxation after the storm surge is gradual at all three stations. Judging from the peak timing at each station the storm surge propagated from north to south at a fast speed of about $30 \mathrm{~m} \mathrm{~s}^{-1}$ that only barotropic coastally trapped waves can measure up. Quantitatively, this phase speed, running through the three stations in only about two hours depends on alongshore variations in wind intensity, wind phase, and bottom topography. The interference of local SSH oscillations with those propagating alongshore complicates the issue further.

\section{TAIWAN STRAIT CURRENT CHOKING}

Typhoon Fanapi perturbed Taiwan Strait Current transport, sea level and upwelling patterns. Strong southward currents under typhoons were observed in the Taiwan Strait (Zhang et al. 2009). Even without typhoons, occasional strong northeasterly winds in winter can reverse the Taiwan Strait transport (Ko et al. 2003). Figure 11 shows the WRF wind stick diagram on top, together with Taiwan Strait transport, averaged SSH over either the Taiwan Strait or ECS shelf south of Changjiang in the bottom panel. Solid and dashed lines are derived from simulations with and without tidal forcing, respectively. Fanapi with its long precursor of northerly winds impacted the ECS and Taiwan Strait days before its landfall over Taiwan (top panel). Two days before Fanapi's landfall over Taiwan the northward transport of the Taiwan Strait began to decrease under the northerly wind. The transport changed from northward to southward around the time Fanapi made its landfall over Taiwan. The rebound came shortly before Fanapi's landfall over China, followed by a damped oscillation. In short, Taiwan Strait transport reversal was tightly confined in the time interval between two landfalls over Taiwan and China. Also of interest is how tides reduce the northward transport by as much as $1 \mathrm{~Sv}$ under normal conditions well before and after Fanapi. Tides enhance bottom boundary layer and therefore bottom drag, retarding the Taiwan Strait Current. The southward propagation of tidal waves (coastal Kelvin waves), when averaged over tidal cycles, is also a potent force pounding southward against the northward development of Taiwan Strait Current (Lee et al. 2014), resulting in reduced transport. Fanapi did not last long over the Taiwan Strait. For this short pulse, localized wind event, Fig. 11 allows us to establish a rough criterion for the northeast wind to stop the northward Taiwan Strait transport. With tidal forcing the critical wind is about $15 \mathrm{~m} \mathrm{~s}^{-1}$ from northeast. Without tidal forcing the corresponding wind is $17 \mathrm{~m} \mathrm{~s}^{-1}$ from the northeast.

The mean sea level over the Taiwan Strait rose gradually before Fanapi's arrival but peaked sharply during Fanapi's transit in the Taiwan Strait. Thereafter it underwent a damped oscillation. The mean SSH over the inner ECS followed a similar variation but with reduced amplitude. Taiwan Strait Current blocking resulted in an SSH rise over the Taiwan Strait as expected, but the concurrent SSH rise over the inner ECS was a little counterintuitive. This was the time of massive Kuroshio intrusion from northeast of Taiwan onto the ECS and even the Taiwan Strait (Fig. 9b), causing SSH over inner ECS to rise from a low a day earlier (Fig. 9a). As the Taiwan Strait Current gushed out after Fanapi the SSH over inner ECS dropped instead. This odd response was caused by the seaward deflection of the Taiwan Strait Current. In its void came SSH drop and cyclonic shear of current shoreward of the current axis (Fig. 9d) that conceivably enhanced upwelling. The lower panel of Fig. 11 also suggests that tidal reduction in Taiwan Strait transport elevated the SSH over inner ECS throughout and also elevated post-Fanapi SSH over the Taiwan Strait.

\section{MID-SHELF UPWELLING MECHANISM OFF SOUTHEAST CHINA}

We select the calm wind, typhoon-free month of August 2010 to examine upwelling mechanisms off southeast China. For both simulations with and without tidal forcing, fields are averaged over two spring-neap cycles from $\mathrm{Au}$ gust 3 to August 31. After time averaging, the latter can be subtracted from the former to derive tidal residuals.

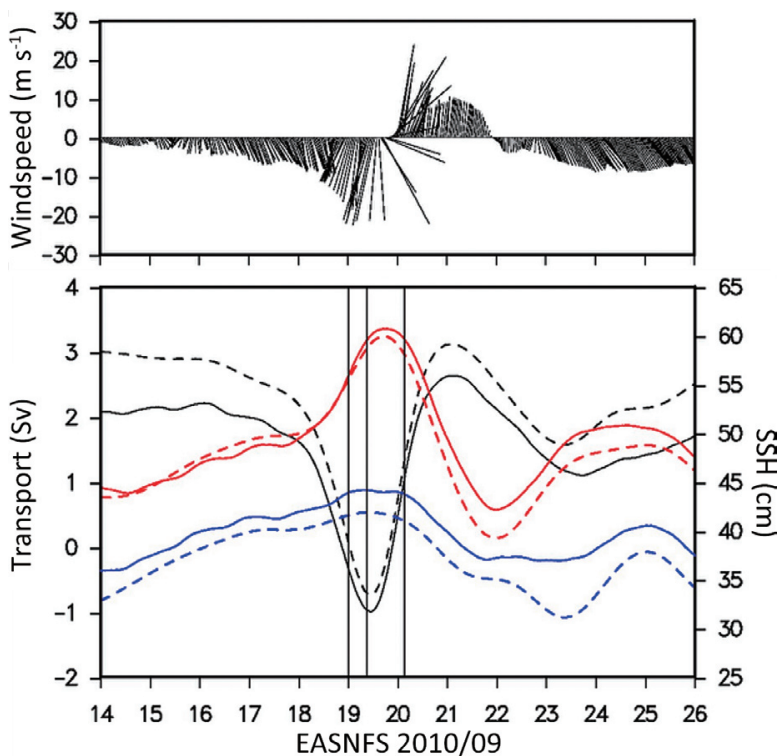

Fig. 11. WRF model produced wind stick diagram on top, followed by de-tided time series of Taiwan Strait transport at $24^{\circ} \mathrm{N}$ (black line), de-tided sea level time series averaged over the Taiwan Strait (red line), and de-tided sea level time series averaged over the ECS from Changjiang mouth southward and within $100 \mathrm{~m}$ water depth (blue line). Solid and dashed lines are with and without tidal forcing, respectively. Vertical intercepts mark the time of Fanapi's landfall over Taiwan, entrance to the Taiwan Strait, and landfall over China. Winds are derived at $\left(23.6^{\circ} \mathrm{N}, 119^{\circ} \mathrm{E}\right)$, where the Taiwan Strait central axis intersected Fanapi's track. 
Figure 12 shows model-produced bottom layer kinetic energy with and without tidal forcing in August. The bottom layer is the layer nearest to the bottom of the model. The effect of bottom topography features stands out. With tidal forcing (Fig. 12a), hot spots show up preferably over distinct topographic features and coincide with upwelling regions. East of the Changjiang mouth the seaward protruding bottom topography produce high bottom kinetic energy and upwelling region 1 (Fig. 5a). Off northeast Taiwan the abruptly widened shelf intersecting the Kuroshio elevates bottom kinetic energy and upwelling in region 2 (Fig. 5a). Penghu Channel upwelling in Fig. 5a also coincides with high bottom kinetic energy in Fig. 12a. Upwelling off southeast China (region 3 in Fig. 5a) presents an exception to the rule for it coincides with regions where bottom kinetic energy is not high (Fig. 12a). This requires in-depth examination. If tidal forcing is excluded (Fig. 12b) hot spots of bottom kinetic energy diminish markedly.

Figure 13 shows the mean surface current superimposed on the mean SST in Fig. 13a and on mean sea surface salinity in Fig. 13b. All variables are averaged over the two springneap cycles in August 2010. Time averaging over nearly a month reduces upwelling intensity to a degree. Dominant features still remain. Along the coast of southeast China is a narrow and sometimes discontinuous band of warm brackish water originating from nearby rivers. From north to south the climatology August runoff temperature is $24.4^{\circ} \mathrm{C}$ from Changjiang, $26.3^{\circ} \mathrm{C}$ from Tsientang River, $28.2^{\circ} \mathrm{C}$ from $\mathrm{Wu}$
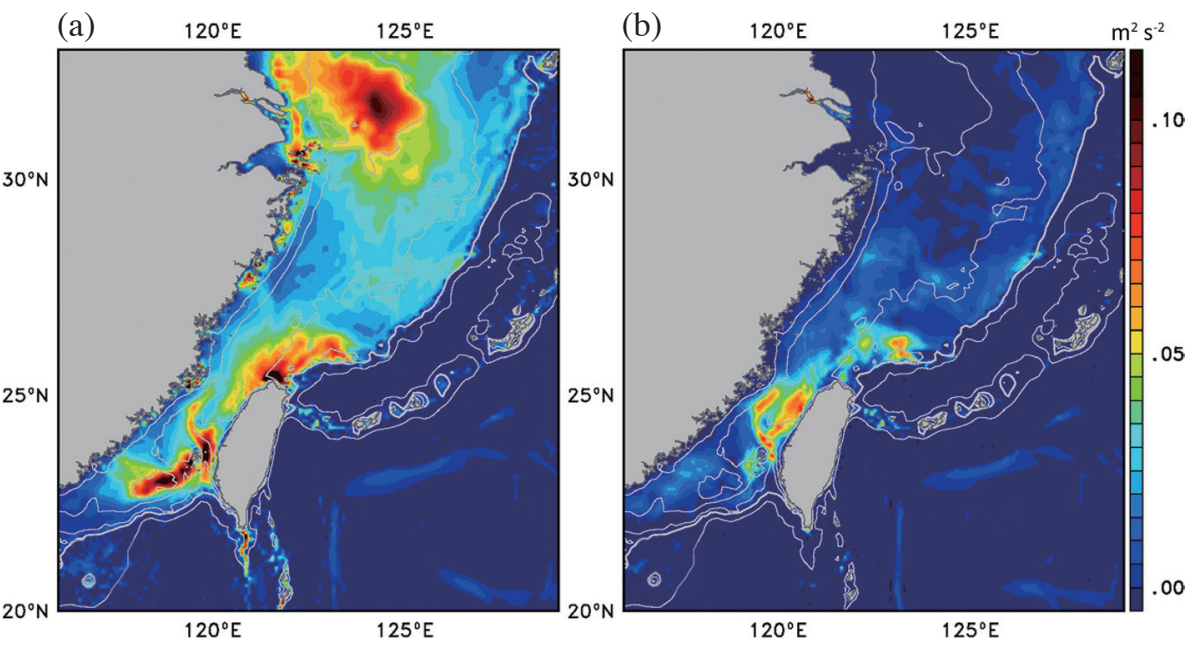

Fig. 12. Model-produced bottom layer kinetic energy divided by the water density, $\left(u^{2}+v^{2}\right) / 2$ in $\mathrm{m}^{2} \mathrm{~s}^{-2}$, averaged over two spring-neap cycles from August 3 to August 31 of 2010 with tidal forcing in (a) and without tidal forcing in (b). Also shown are 25, 50, 100, 200, and 1000 m isobaths.
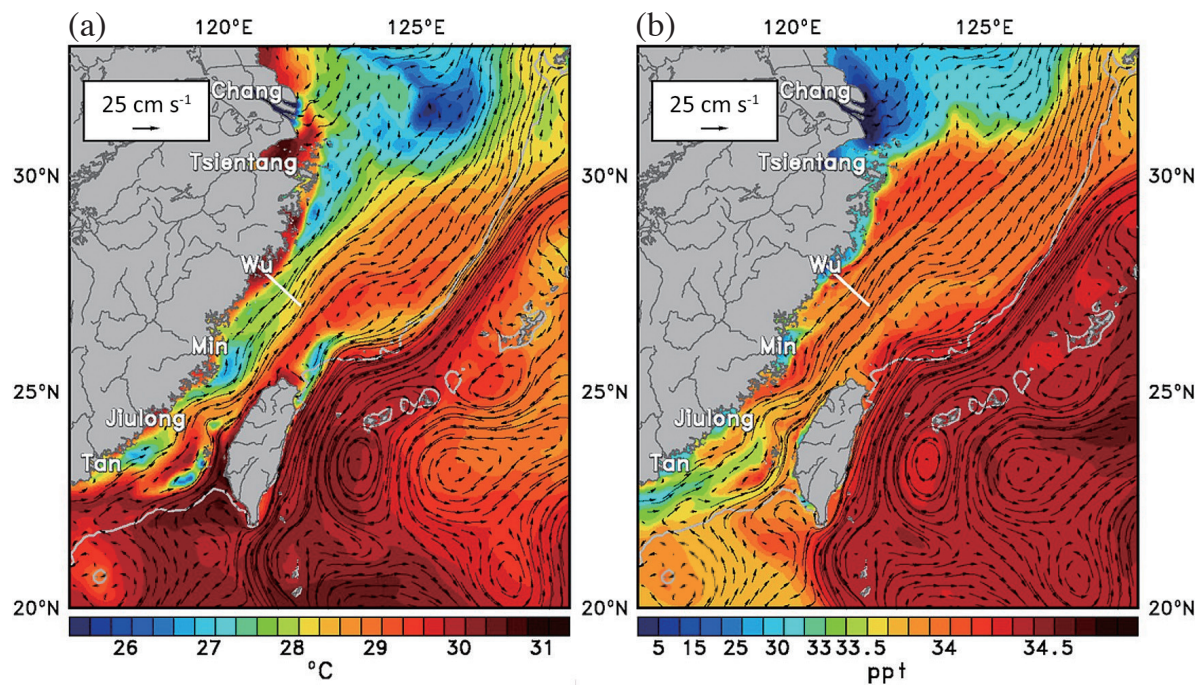

Fig. 13. Mean surface current superimposed on (a) mean SST and (b) mean surface salinity, along with locations of model-imposed river forcing from Changjiang southward. All variables are averaged over the first two spring-neap cycles from August 3 to August 31 of 2010 . Gray line indicates $200 \mathrm{~m}$ isobath. A shore-normal transect is indicated by a thick white segment. 
River, $27.3^{\circ} \mathrm{C}$ from Min River, $27.1^{\circ} \mathrm{C}$ from Jiulong River, and $27.7^{\circ} \mathrm{C}$ from Tan River. The coastal band of brackish water is generally $1-2^{\circ} \mathrm{C}$ warmer, apparently enhanced by August insolation under the calm wind condition.

The Taiwan Strait Current is continuously deflected seaward (eastward) as it moves northward. Upwelling is sandwiched between the coastal band of warm, brackish water and the axis of the Taiwan Strait Current off southeast China. This upwelling is characterized by cooler SST (Fig. 13a) and slightly lower salinity (Fig. 13b).

Figure 14 shows shore-normal transects of temperature and cross-shelf velocity in Fig. 14a, temperature and alongshore velocity in Fig. 14b, salinity and cross-shelf velocity in Fig. 14c, and temperature and vertical velocity in Fig. 14d. This transect, as indicated by a white segment in Fig. 13, intersects the coast at $27.5^{\circ} \mathrm{N}$. All variables are averaged over two spring-neap cycles in August. The mean alongshore current with its axis over the mid-shelf, extends from surface to bottom (Fig. 14b), driving a landward and up-slope bottom Ekman flow and returns seaward flow aloft (Figs. 14a and c). As the alongshore current weakens landward the bottom Ekman flow also decelerates landward accordingly. The consequent convergence of bottom landward current drives up- welling on the shoreward side of the alongshore current axis (Fig. 14d). The landward bottom Ekman flow brings colder and saltier water up the slope (Figs. 14a and c). It also prevents the coastal band of warm brackish water from spreading offshore. Trowbridge and Lentz (1991) provided a detailed analysis of this bottom Ekman layer.

Figure 15 shows depth-averaged tidal residual current superimposed on tidal residual SST in Fig. 15a and tidal residual sea surface salinity in Fig. 15b. Again, all variables are averaged over two spring-neap cycles in August. Depth averaging is meant to remove deep ocean features such as internal tide residuals. From the Changjiang mouth southward to the South China Sea the coastal tidal residual current is southward throughout. As noted earlier in Lee et al. (2014) tides propagate from the Changjiang mouth southward in the form of a coastal Kelvin wave. Flood tide carries a higher momentum flux southward while the ebb tide carries a lower momentum flux northward. The residual current is southward when averaged over tidal cycles. The southward tidal residual current is associated with a coastal band of residual warm and fresher anomalies. The tidal residual also enhances cold SST in the Changjiang plume region, off northeast Taiwan, and over Penghu Channel. As in Lee et al. (2014), the (a)
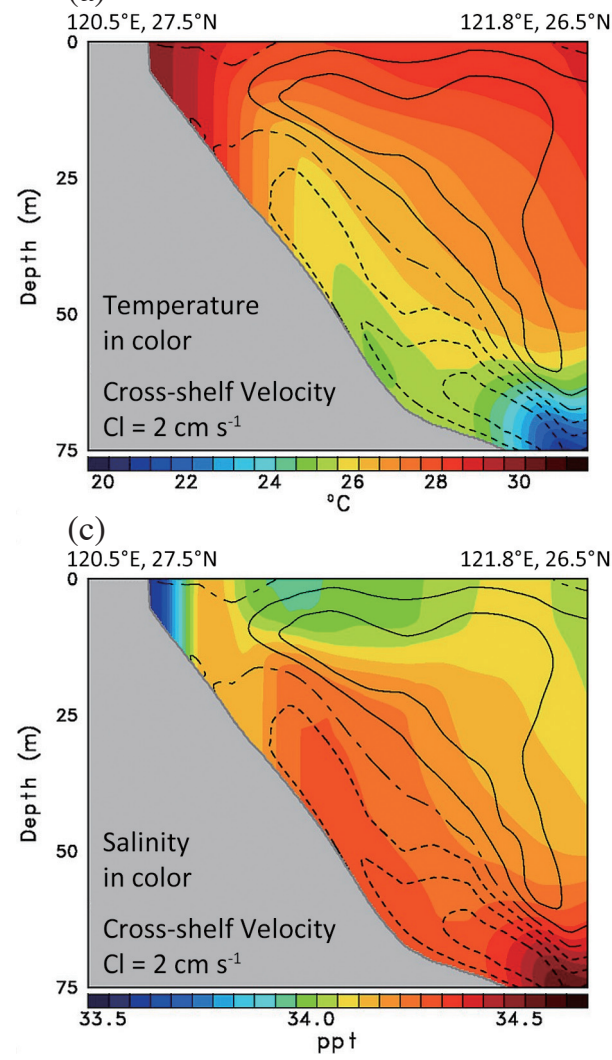

(b)

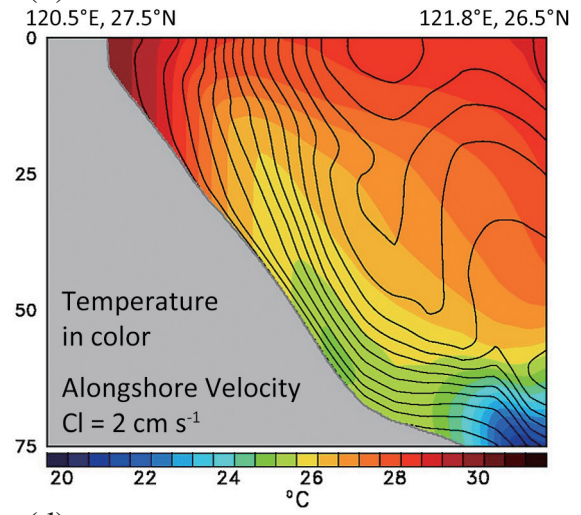

(d)

$120.5^{\circ} \mathrm{E}, 27.5^{\circ} \mathrm{N} \quad 121.8^{\circ} \mathrm{E}, 26.5^{\circ} \mathrm{N}$

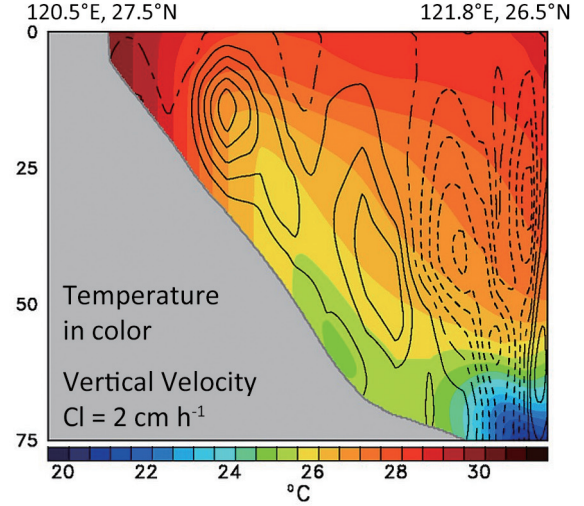

Fig. 14. Shore-normal transects of (a) temperature and cross-shelf velocity, (b) temperature and alongshore velocity, (c) salinity and cross-shelf velocity, and (d) temperature and vertical velocity. Variables are averaged over two spring-neap cycles from August 3 to August 31 of 2010 . Solid isotachs are northeastward (left-bounded), seaward or upward, while dashed isotachs are southwestward, landward or downward. Dot-dashed lines delineate regions of opposite flows. 

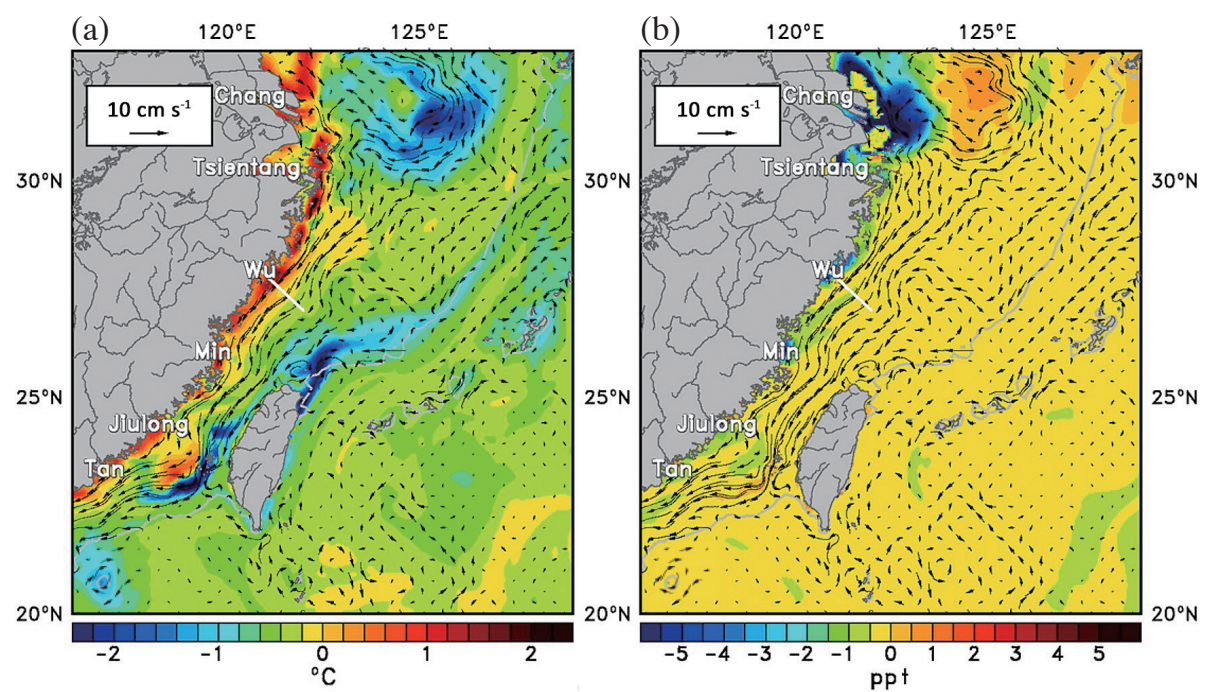

Fig. 15. Depth-averaged tidal residual current superimposed on (a) tidal residual SST and (b) tidal residual surface salinity. Conventions are otherwise the same as in Fig. 13.

anticyclonic tidal residual current off the Changjiang mouth also enhances fresher water seaward spreading.

The shore-normal transect of tidal residuals (Fig. 16) reveals subsurface features. The tidal residual coastal jet is weaker, narrower and closer to shore (Fig. 16b) than the northward Taiwan Strait Current (Fig. 14b). It also extends from surface to bottom, inducing a seaward, downslope bottom Ekman flow and return landward flow immediately above it (Figs. 16a and c). As the bottom Ekman flow is more or less proportional to the alongshore jet speed directly above, it first accelerates and subsequently decelerates as it flows seaward across the jet axis. The consequent flow divergence and convergence induce downwelling shoreward of the jet axis and upwelling seaward of it (Fig. 16d). The slanted downdraft along the sloping bottom also carries warm and fresher water with it (Figs. 16a and c). Thus in addition to the direct action of oscillating tidal currents, tidal residual flow also contributes to bottom de-stratification. If tidal forcing is excluded, stratification strengthens but upwelling weakens (results not shown).

In summary, Fig. 17a schematically illustrates the relation among the mean Taiwan Strait Current, variation in bottom Ekman flow, nearshore water mass anomaly, upwelling and transverse flow. As revealed in satellite SST images (e.g., Fig. 3c) the nearshore water mass anomaly may be patchier than illustrated at times. The bottom Ekman flow brings colder and saltier water shoreward. The corresponding tidal residuals are illustrated in Fig. 17b. Again, the nearshore tidal residual water mass anomaly may be patchier. In this case the bottom Ekman flow carries warmer and fresher water seaward. Tidal enhancement of upwelling off southeast China becomes more apparent. Wedging southward on the shoreward side the tidal residual current has the ability to shift the Taiwan Strait Current axis offshore as noted ear- lier in Lee et al. (2014). The widened cyclonic vorticity area shoreward of the Taiwan Strait Current is expected to expand the mid-shelf upwelling area off southeast China.

\section{PENGHU CHANNEL UPWELLING}

Figure 18 conceptualizes transverse circulation under normal summer setting well before the appearance of Fanapi. The upslope bottom current over the western flank of Penghu Channel (region 4 in Fig. 5a) is a bottom Ekman layer associated with the northward Penghu Channel current, producing upwelling. Viewing northward the transverse circulation pattern essentially consists of two clockwise cells. The left one is bottom intensified over the banks shallower than $70 \mathrm{~m}$ whereas the right one is deeper, top intensified and essentially extends through the entire depth of the deep channel. As we will discuss below the doublecell structure is essentially a result of breakup from a single cell that would exist in the vanishing stratification limit and smoothly varying cross-channel bottom topography.

Figure 19 shows the de-tided transverse circulation features centered at 0000 UTC September 12. Tidal forcing was included. Tides consistently enhance vertical motions and thicken the bottom Ekman layer markedly. Corresponding results without tidal forcing are therefore not shown for brevity. At this time Fanapi had not formed yet. The northwest-southeast transverse section, indicated by a segment at the sea surface in Fig. 18, is normal to the principal channel axis that runs from southwest to northeast. In essence the vertical velocity fields (Fig. 19a) essentially consist of two upwelling-downwelling pairs. The left (west) pair is over the banks shallower than $70 \mathrm{~m}$. The right (east) pair over the deep channel essentially extends through the water column. Tides generally enhance vertical velocities especially in the 
west side of the deep channel. Isotherms in Fig. 19a generally deepen eastward to support a northward along-channel flow. Temperature fields show bottom boundary layer produced by the upslope Ekman flow along the west side of deep channel. The bottom boundary layer would have been thinner without tidal forcing.

Figure 19b shows de-tided along-channel velocity (in color) and cross-channel velocity (in black contours). The northward along-channel flow attenuated downward

(a)

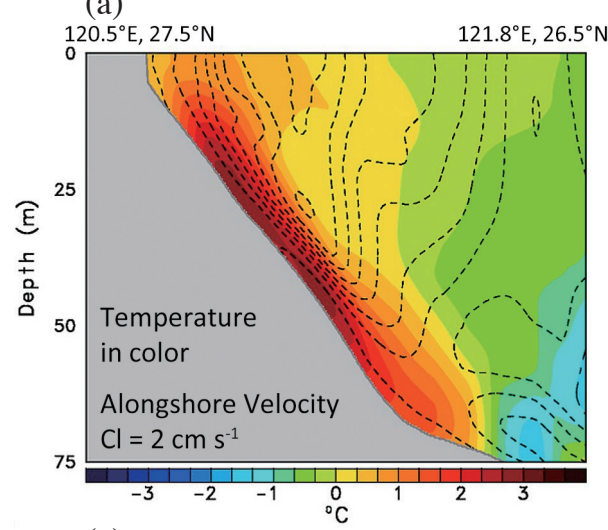

(c)

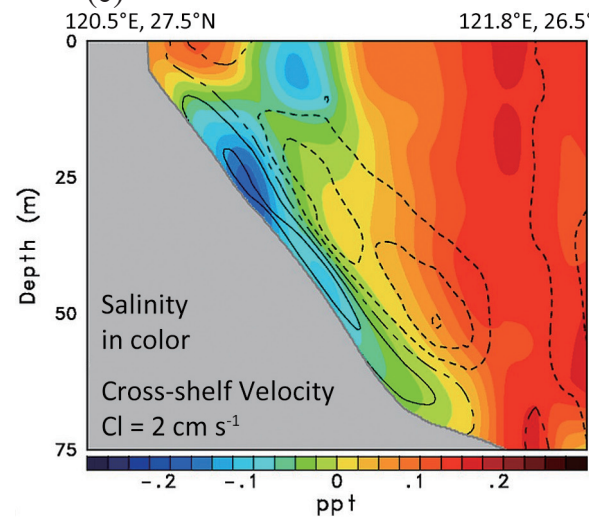

throughout the water column except for a narrow and weak, southward undercurrent over the eastern slope of Penghu Channel. It grew as the Penghu Channel current migrated to the west and decayed as the current migrated to the east. The northward Penghu Channel current is otherwise throughout the channel. The condition is favorable for the development of an upslope bottom current along the western slope of the channel. Upslope movement of colder, denser water must overcome water density decrease over the distance traveled.

(b)

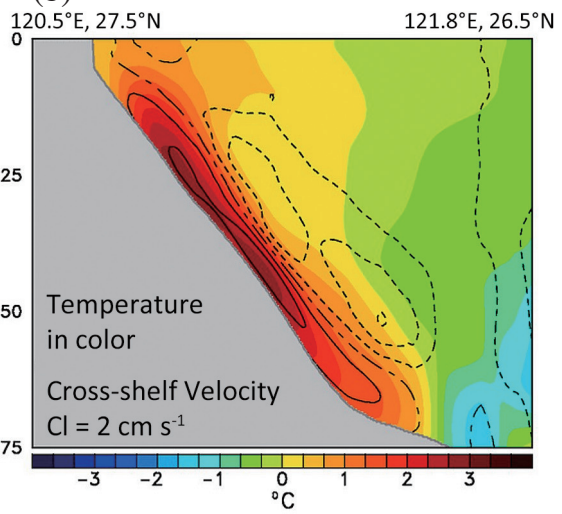

(d)

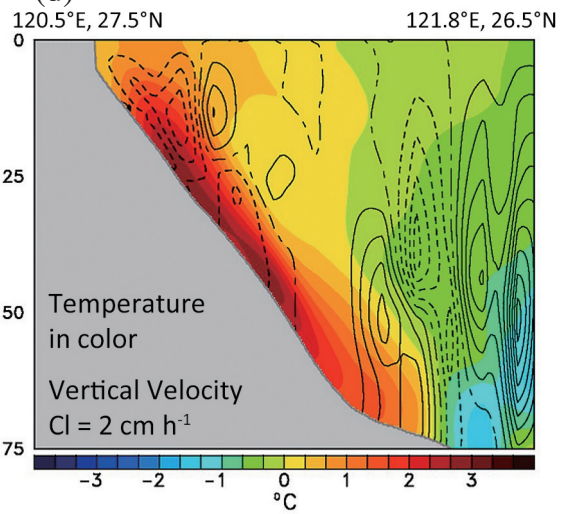

Fig. 16. Same as Fig. 14 except for tidal residuals (a) temperature and cross-shelf velocity, (b) temperature and alongshore velocity, (c) salinity and cross-shelf velocity, and (d) temperature and vertical velocity.
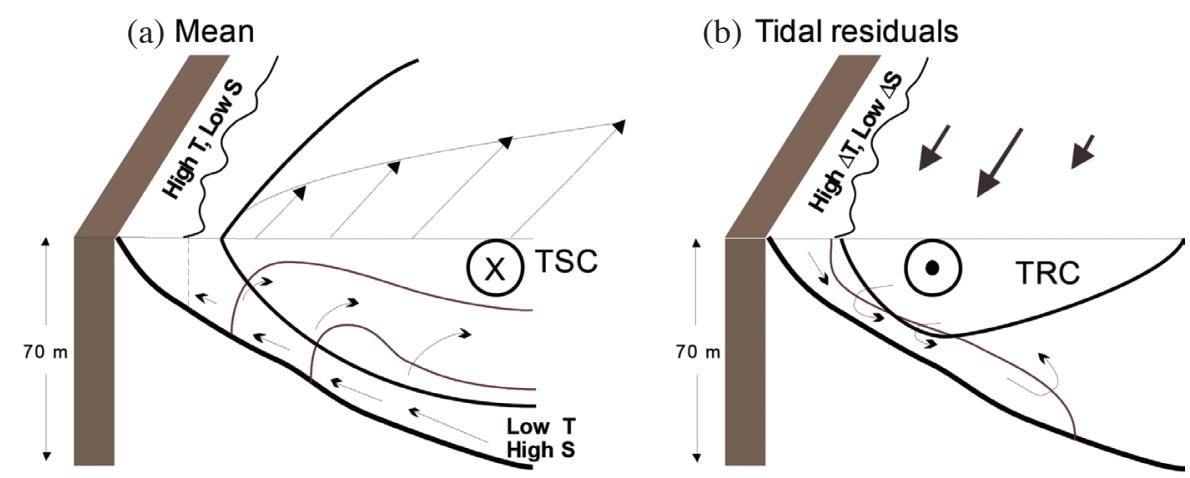

Fig. 17. Schematic illustrations of (a) mean three-dimensional circulation associated with Taiwan Strait Current (TSC), isopycnals in red, and sources of temperature $(\mathrm{T})$ and salinity $(\mathrm{S})$ anomalies, and (b) corresponding tidal residual current (TRC), isopycnals in red, temperature and salinity anomalies $(\Delta \mathrm{T}$ and $\Delta \mathrm{S})$. (Color online only) 


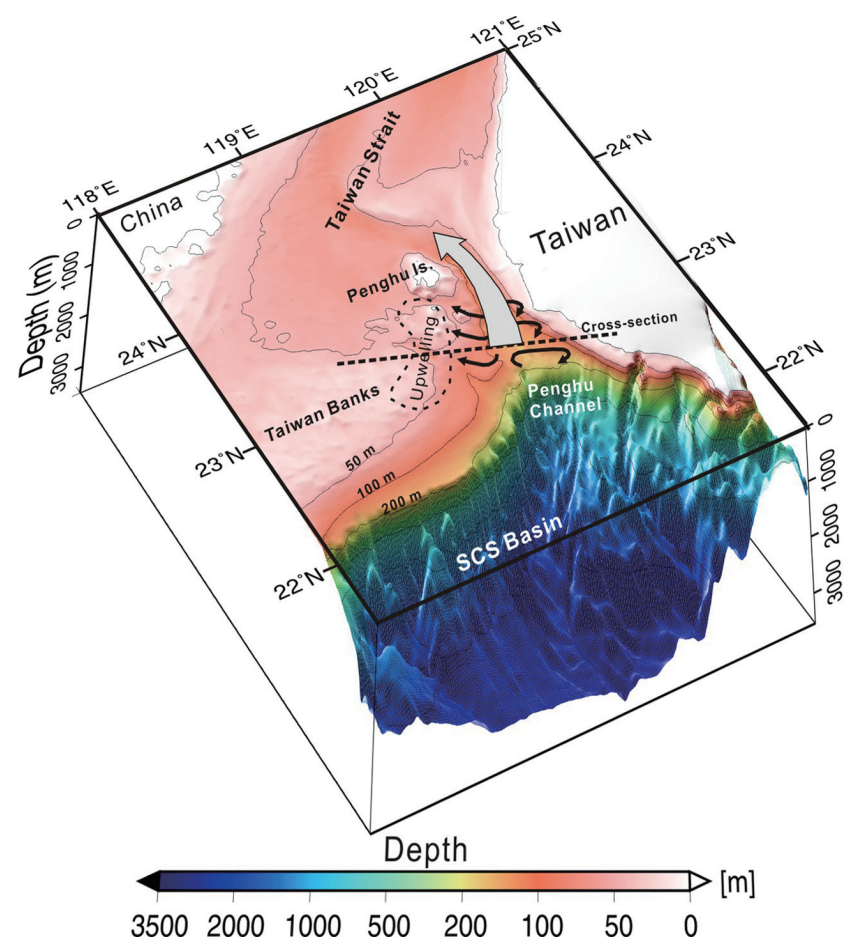

Fig. 18. A conceptual model of summer upwelling around the Penghu Channel. Upslope bottom current on the western and northern sides of the northward Penghu Channel current produces upwelling with the aid of tidally induced de-stratification. The transverse circulation consists of two clockwise gyres; the west one is over the banks shallower than $70 \mathrm{~m}$. A northwest-southeast section as illustrated by a segment at the sea surface from $\left(118.7^{\circ} \mathrm{E}, 23.3^{\circ} \mathrm{N}\right)$ to $\left(120.3^{\circ} \mathrm{E}, 22.7^{\circ} \mathrm{N}\right)$ will be used to show transverse circulation features.

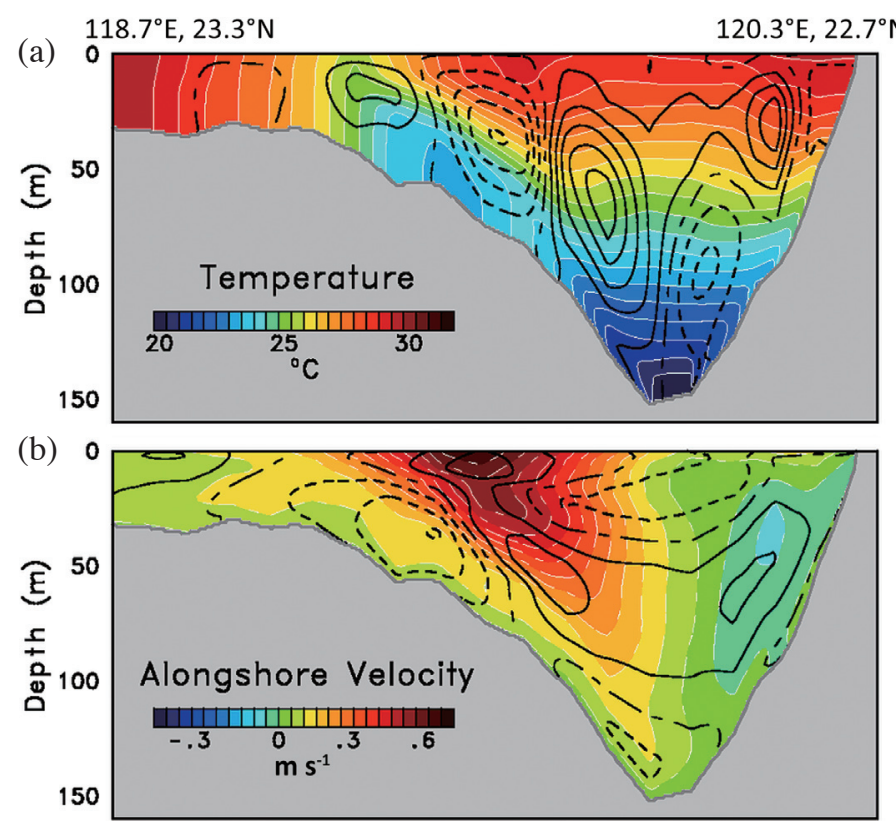

Fig. 19. Northward, pre-Fanapi view of (a) temperature (color contours: $\mathrm{CI}=0.5^{\circ} \mathrm{C}$ ) with vertical velocity (black contour: $\left.\mathrm{CI}=0.25 \mathrm{~m} \mathrm{~h}^{-1}\right)$ and (b) along-channel velocity (color contours: $\mathrm{CI}=0.05 \mathrm{~m} \mathrm{~s}^{-1}$ ) and cross-channel velocity (black contours: $\mathrm{CI}=0.05 \mathrm{~m} \mathrm{~s}^{-1}$ ) at a northwest-southeast oriented cross-section normal to the principal axis of the Penghu Channel from $\left(118.7^{\circ} \mathrm{E}, 23.3^{\circ} \mathrm{N}\right)$ to $\left(120.3^{\circ} \mathrm{E}, 22.7^{\circ} \mathrm{N}\right)$ at $0000 \mathrm{UTC} 12 \mathrm{September}$ 2010. Model outputs are de-tided with low-pass filter using 42-h Lanczos taper. Solid isotachs are eastward, northward and upward; dashed ones are opposite. 
This inhibition of upslope movement decreases with bottom de-stratification or over a gentler bottom slope. Both conditions are met over the western slope of Penghu Channel in waters shallower than about $70 \mathrm{~m}$. Not surprisingly, westward (and therefore upslope) bottom current develops over the western slop (Fig. 19b).

In limits of vanishing stratification and smoothly varying cross-channel bottom profile, a single-cell transverse circulation with westward bottom flow and eastward surface flow is likely to develop across the entire channel. Without stratification the bottom Ekman flow can continue unopposed along sloping bottom. The absence of a bottom slope break is also likely to stabilize the single-cell formation. Both limits are not met in the Penghu Channel. In consequence the double-cell structure develops.

Figure 20 shows the Fanapi-perturbed transverse circulation at 1200 UTC September 19. The timing was midway between Figs. 9b and c. At this time Fanapi's eye is over the Penghu Channel (Figs. 4 or 9). This was also the approximate time the northerly wind in the front half of Fanapi had exerted its maximum impact on Penghu Channel current, in which the top $25 \mathrm{~m}$ current became southward (downwind), overlying a persistent northward Penghu Channel flow (Fig. 20b). Over the shallow banks on the west side of the channel, the downwind current is toward channel axis and southward; the down-slope current entailed downwelling (Fig. 20a). Over the deep channel the up-channel undercurrent and down-channel surface current resembled a two-layered circulation pattern in estuaries while upwelling ensued (Fig. 20a). As far as the bulk of shallow Taiwan Strait was concerned the Taiwan Strait Current choking was complete at this time.

\section{CONCLUSION}

Among the three upwelling regions in the seas around Taiwan upwelling off the northeast Taiwan appears to be the most pronounced. Leaving tidal forcing aside the mean current generates the strongest upwelling over the steepest bottom slope. Including tidal forcing, tide-induced upwelling is also the strongest over the steepest bottom slope. Not surprisingly, upwelling off northeast Taiwan stands out as the most pronounced. The mid-shelf upwelling off southeast China and Penghu Channel upwelling have not received due attentions. We therefore investigate further into their formation mechanisms in conjunction with Fanapi-induced perturbations.

Moving along an essentially westward track Typhoon Fanapi (2010) made a modest $\left(>4 \mathrm{~m} \mathrm{~s}^{-1}\right)$ transit across Taiwan on September 19, entered the Taiwan Strait $15 \mathrm{~h}$ later, and made the second landfall over China on September 20. Its impact was not limited to local storm surges along the east coasts of Taiwan and China. To the contrary, the impact extended from the southern end of Taiwan Strait northward to at least Changjiang mouth. This is the conclusion we derived from an ocean model using typhoon-resolving atmospheric forcing. In addition to producing a pronounced cold wake in the open ocean, Fanapi in general enhanced upwelling in the seas around Taiwan. The perturbations made by Fanapi allowed us to better understand the role of the Taiwan Strait Current in maintaining the ECS circulation. Under normal settings the shelf break area northeast of Taiwan is the confluence zone of the Kuroshio and Taiwan Strait Current. The two tended to wax and wane at the expense of each other. In summer the southwest monsoon enhanced the Taiwan

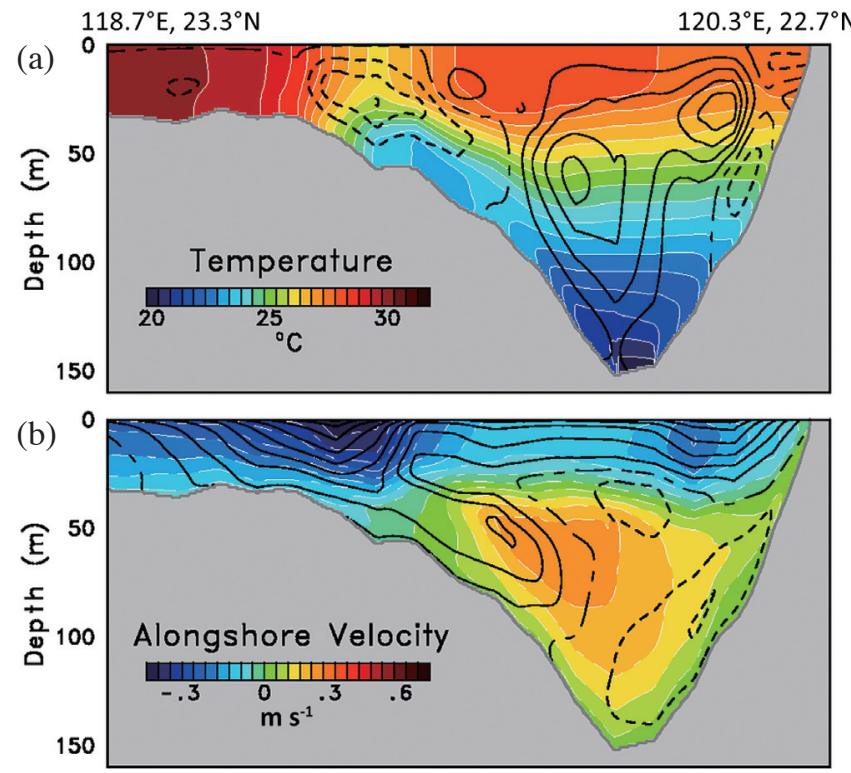

Fig. 20. Same as Fig. 19 except under the direct influence of Fanapi at 1200 UTC 19 September 2010 (a) temperature with vertical velocity and (b) along-channel velocity and cross-channel velocity. 
Strait Current which pushed the Kuroshio offshore, enhancing upwelling and the associated cyclonic eddy off northeast Taiwan. In winter the northeast monsoon suppressed the Taiwan Strait Current while inviting the Kuroshio to intrude onto ECS (e.g., Wu et al. 2008). Fanapi tipped the balance in favor of an extreme that is far beyond typical winter-like conditions. The Taiwan Strait Current was reversed and massive Kuroshio intrusion onto ECS and northern Taiwan Strait ensued. Even under this abnormal extreme upwelling off southeast China still persisted presumably with the aid of wind-induced de-stratification. As the Taiwan Strait Current restarted and deflected seaward after Fanapi, low SSH, cyclonic current shear and upwelling returned to normal conditions in regions shoreward of its axis.

In modeling circulation over continental shelves tides have been mostly excluded for computational efficiency and to ease presentation and interpretation problems. Oscillations due to tides have therefore been previously isolated mostly in the high-frequency domain and investigated separately from mean circulation. In this study we have highlighted the importance of tides in enhancing low-frequency mean circulation features such as upwelling over the shelf or topographic features. Mechanisms leading to tidal enhancement vary. For the most part tides de-stratify water columns through orographic lifting over bottom features and enhance bottom stress, allowing upwelling to develop better. Under normal summer conditions in the present model tides also reduce the Taiwan Strait transport by about $1 \mathrm{~Sv}$, largely by enhancing the bottom drag and southward tidal wave propagation. In this light tidal forcing may not be as conveniently neglected in study of mean circulation on the shelves as in the past for the sake of simplification.

Acknowledgements Authors DSK and SYC were supported by the US Office of Naval Research (ONR) grants N00014-08WX-2-1170 and N00014-09-1-0623, respectively. Author CCW was supported by Taiwan's National Science Council (NSC) grant NSC97-2111-M-002-397016MY3 and ONR grant N00014-10-1-0725. Author IIL was supported by NSC grants: NSC101-2111-M-002-MY2 and NSC101-2628-M-002/-001-MY4; 102R7803. Author SJ was supported by NSC98-2611-M-002-019-MY3. We appreciate detail and helpful comments from R. C. Lien and an Anonymous Reviewer.

\section{REFERENCES}

Carnes, M. R., D. N. Fox, R. C. Rhodes, and O. M. Smedstad, 1996: Data assimilation in a North Pacific Ocean monitoring and prediction system. Elsevier Oceanogr. Ser.,61,319-345, doi: 10.1016/S0422-9894(96)800158. [Link]

Chang, Y. L., C. R. Wu, and L. Y. Oey, 2009: Bimodal behavior of the seasonal upwelling off the northeastern coast of Taiwan. J. Geophys. Res., 114, C03027, doi: 10.1029/2008JC005131. [Link]

Chang, Y. T., T. Y. Tang, S. Y. Chao, M. H. Chang, D. S. Ko, Y. J. Yang, W. D. Liang, and M. J. McPhaden, 2010: Mooring observations and numerical modeling of thermal structures in the South China Sea. J. Geophys. Res., 115, C10022, doi: 10.1029/2010JC006293. [Link]

D'Asaro, E. A., P. G. Black, L. R. Centurioni, Y. T. Chang, S. S. Chen, R. C. Foster, H. C. Graber, P. Harr, V. Hormann, R. C. Lien, I. I. Lin, T. B. Sanford, T. Y. Tang, and C. C. Wu, 2014: Impact of Typhoons on the Ocean in the Pacific. Bull. Amer. Meteorol. Soc., 95, 14051418, doi: 10.1175/BAMS-D-12-00104.1. [Link]

Donelan, M. A., B. K. Haus, N. Reul, W. J. Plant, M. Stiassnie, H. C. Graber, O. B. Brown, and E. S. Saltzman, 2004: On the limiting aerodynamic roughness of the ocean in very strong winds. Geophys. Res. Lett., 31, L18306, doi: 10.1029/2004GL019460. [Link]

Egbert, G. D. and S. Y. Erofeeva, 2002: Efficient inverse modeling of barotropic ocean tides. J. Atmos. Ocean. Technol., 19, 183-204, doi: 10.1175/1520-0426(2002) 019<0183:EIMOBO>2.0.CO;2. [Link]

Fox, D. N., W. J. Teague, C. N. Barron, M. R. Carnes, and C. M. Lee, 2002: The Modular Ocean Data Assimilation System (MODAS). J. Atmos. Ocean. Technol., 19, 240-252, doi: 10.1175/1520-0426(2002)019<0240:T MODAS $>2.0 . C O ; 2$. [Link]

Gopalakrishnan, G., B. D. Cornuelle, G. Gawarkiewicz, and J. L. McClean, 2013: Structure and evolution of the cold dome off northeastern Taiwan: A numerical study. Oceanography, 26, 66-79, doi: 10.5670/oceanog.2013.06. [Link]

Hong, H., F. Chai, C. Zhang, B. Huang, Y. Jiang, and J. $\mathrm{Hu}, 2011$ : An overview of physical and biogeochemical processes and ecosystem dynamics in the Taiwan Strait. Cont. Shelf Res., 31, S3-S12, doi: 10.1016/j. csr.2011.02.002. [Link]

Hu, J., H. Kawamura, H. Hong, M. Suetsugu, and M. Lin, 2001: Hydrographic and satellite observations of summertime upwelling in the Taiwan Strait: A preliminary description. Terr. Atmos. Ocean. Sci., 12, 415-430.

Jan, S., J. Wang, C. S. Chern, and S. Y. Chao, 2002a: Seasonal variation of the circulation in the Taiwan Strait. J. Mar. Syst., 35, 249-268, doi: 10.1016/S09247963(02)00130-6. [Link]

Jan, S., C. S. Chern, and J. Wang, 2002b: Transition of tidal waves from the East to South China Seas over the Taiwan Strait: Influence of the abrupt step in the topography. J. Oceanogr., 58, 837-850, doi: 10.1023/A:1022827330693. [Link]

Jan, S., C. C. Chen, Y. L. Tsai, Y. J. Yang, J. Wang, C. S. Chern, G. Gawarkiewicz, R. C. Lien, L. Centurioni, and J. Y. Kuo, 2011: Mean structure and variability of 
the cold dome northeast of Taiwan. Oceanography, 24, 100-109, doi: 10.5670/oceanog.2011.98. [Link]

Ko, D. S. and D. P. Wang, 2014: Intra-Americas Sea Nowcast/Forecast System Ocean Reanalysis to Support Improvement of Oil-Spill Risk Analysis in the Gulf of Mexico by Multi-Model Approach, Department of the Interior, Bureau of Ocean Energy Management, Herndon, VA, BOEM 2014-1003.

Ko, D. S., R. H. Preller, G. A. Jacobs, T. Y. Tang, and S. F. Lin, 2003: Transport reversals at Taiwan Strait during October and November 1999. J. Geophys. Res., 108, doi: 10.1029/2003JC001836. [Link]

Ko, D. S., P. J. Martin, C. D. Rowley, and R. H. Preller, 2008: A real-time coastal ocean prediction experiment for MREA04. J. Mar. Syst., 69, 17-28, doi: 10.1016/j. jmarsys.2007.02.022. [Link]

Ko, D. S., S. Y. Chao, P. Huang, and S. F. Lin, 2009: Anomalous upwelling in Nan Wan: July 2008. Terr. Atmos. Ocean. Sci., 20, 839-852, doi: 10.3319/ TAO.2008.11.25.01(Oc). [Link]

Large, W. G., J. C. McWilliams, and S. C. Doney, 1994: Oceanic vertical mixing: A review and a model with a nonlocal boundary layer parameterization. Rev. Geophys., 32, 363-403, doi: 10.1029/94RG01872. [Link]

Lee, H. J., S. Y. Chao, K. K. Liu, S. J. Huang, and G. C. Gong, 2014: Tidal effects on circulation in and near the East China Sea. Terr. Atmos. Ocean. Sci., 25, 233-254, doi: 10.3319/TAO.2013.10.08.01(Oc). [Link]

Lee, I. H., D. S. Ko, Y. H. Wang, L. Centurioni, and D. P. Wang, 2013: The mesoscale eddies and Kuroshio transport in the western North Pacific east of Taiwan from 8-year (2003-2010) model reanalysis. Ocean Dyn., 63, 1027-1040, doi: 10.1007/s10236-013-0643-z. [Link]

Lefèvre, F., C. Le Provost, and F. H. Lyard, 2000: How can we improve a global ocean tide model at a regional scale? A test on the Yellow Sea and the East China Sea. J. Geophys. Res., 105, 8707-8725, doi: 10.1029/1999JC900281. [Link]

Lin, I. I., C. C. Wu, I. F. Pun, and D. S. Ko, 2008: Upperocean thermal structure and the western North Pacific category 5 typhoons. Part I: Ocean features and the category 5 typhoons' intensification. Mon. Weather Rev., 136, 3288-3306, doi: 10.1175/2008MWR2277.1. [Link]

Lin, I. I., P. Black, J. F. Price, C. Y. Yang, S. S. Chen, C. C. Lien, P. Harr, N. H. Chi, C. C. Wu, and E. A. D'Asaro, 2013: An ocean coupling potential intensity index for tropical cyclones. Geophys. Res. Lett., 40, 1878-1882, doi: 10.1002/grl.50091. [Link]

Liu, K. K., G. C. Gong, C. Z. Shyu, S. C. Pai, C. L. Wei, and S. Y. Chao, 1992: Response of Kuroshio upwelling to the onset of the northeast monsoon in the sea north of Taiwan: Observations and a numerical simulation. J. Geophys. Res., 97, 12511-12526, doi:

\subsection{9/92JC01179. [Link]}

Lou, X., A. Shi, Q. Xiao, and H. Zhang, 2011: Satellite observation of the Zhejiang coastal upwelling in the East China Sea during 2007-2009. Proc. SPIE, 8175, doi: 10.1117/12.898140. [Link]

Lü, X., F. Qiao, C. Xia, and Y. Yuan, 2007: Tidally induced upwelling off Yangtze River estuary and in Zhejiang coastal waters in summer. Sci. China Ser. D, 50, 462473, doi: 10.1007/s11430-007-2050-0. [Link]

Martin, P. J., 2000: Description of the Navy Coastal Ocean Model Version 1.0. NRL Report, NRL/FR/7322-009962, Naval Research Laboratory, 42 pp.

Mrvaljevic, R. K., P. G. Black, L. R. Centurioni, Y. T. Chang, E. A. D'Asaro, S. R. Jayne, C. M. Lee, R. C. Lien, I. I. Lin, J. Morzel, P. P. Niiler, L. Rainville, and T. B. Sanford, 2013: Observations of the cold wake of Typhoon Fanapi (2010). Geophys. Res. Lett., 40, 316321. doi: 10.1029/2012GL054282. [Link]

Niwa, Y. and T. Hibiya, 2004: Three-dimensional numerical simulation of $\mathrm{M}_{2}$ internal tides in the East China Sea. J. Geophys. Res., 109, C04027, doi: 10.1029/2003JC001923. [Link]

Price, J. F., 1981: Upper ocean response to a hurricane. J. Phys. Oceanogr., 11, 153-175, doi: 10.1175/1520-048 5(1981)011<0153:UORTAH>2.0.CO;2. [Link]

Rosmond, T. E., 1992: The design and testing of the Navy Operational Global Atmospheric Prediction System. Weather Forecast., 7, 262-272. doi: 10.1175/1520-043 4(1992)007<0262:TDATOT>2.0.CO;2. [Link]

Trowbridge, J.H. and S. J.Lentz, 1991: Asymmetric behavior of an oceanic boundary layer above a sloping bottom. $J$. Phys. Oceanogr., 21, 1171-1185, doi: 10.1175/1520-04 85(1991)021<1171:ABOAOB > 2.0.CO;2. [Link]

Tseng, Y. F., J. Lin, M. Dai, and S. J. Kao, 2013: Joint effect of freshwater plume and coastal upwelling on phytoplankton growth off the Changjiang River. Biogeosciences Discuss., 10, 10363-10397, doi: 10.5194/bgd10-10363-2013. [Link]

Wu, C. C., P. H. Lin, S. Aberson, T. C. Yeh, W. P. Huang, K. H. Chou, J. S. Hong, G. C. Lu, C. T. Fong, K. C. Hsu, I. I. Lin, P. L. Lin, and C. H. Liu, 2005: Dropwindsonde Observations for Typhoon Surveillance near the Taiwan Region (DOTSTAR): An overview. Bull.Amer.Meteorol.Soc., 86, 787-790, doi: 10.1175/ BAMS-86-6-787. [Link]

Wu, C. C., G. Y. Lien, J. H. Chen, and F. Zhang, 2010: Assimilation of tropical cyclone track and structure based on the Ensemble Kalman Filter (EnKF). J. Atmos. Sci., 67, 3806-3822, doi: 10.1175/2010JAS3444.1. [Link]

Wu, C. C., Y. H. Huang, and G. Y. Lien, 2012: Concentric eyewall formation in Typhoon Sinlaku (2008). Part I: Assimilation of T-PARC data based on the ensemble Kalman filter (EnKF). Mon. Weather Rev., 140, 506527, doi: 10.1175/MWR-D-11-00057.1. [Link] 
Wu, C. R., H. F. Lu, and S. Y. Chao, 2008: A numerical study on the formation of upwelling off northeast Taiwan. J. Geophys. Res., 113, C08025, doi: 10.1029/2007JC004697. [Link]

Wu, H., J. Zhu, J. Shen, and H. Wang, 2011: Tidal modulation on the Changjiang River plume in summer. J. Geophys. Res., 116, C08017, doi: 10.1029/2011JC007209. [Link]

Yang, D., B. Yin, J. Sun, and Y. Zhang, 2013: Numerical study on the origins and the forcing mechanism of the phosphate in upwelling areas off the coast of Zhejiang province, China in summer. J. Mar. Syst., 123-124, 1-18, doi: 10.1016/j.jmarsys.2013.04.002. [Link]

Zedler, S. E., 2009: Simulations of the ocean response to a hurricane: Nonlinear processes. J. Phys. Oceanogr., 39, 2618-2634, doi: 10.1175/2009JPO4062.1. [Link]

Zhang, W. Z., H. S. Hong, S. P. Shang, X. H. Yan, and F. Chai, 2009: Strong southward transport events due to typhoons in the Taiwan Strait. J. Geophys. Res., 114, C11013, doi: 10.1029/2009JC005372. [Link] 